BULLETIN Bulletin hispanique

HISPANIQUE Université Michel de Montaigne Bordeaux

109-2 | 2007

La formation du Parnasse espagnol $\mathrm{XV}^{\mathrm{e}}-\mathrm{XVIII}{ }^{\mathrm{e}}$ siècle

\title{
La literatura española en la Agudeza de Gracián
}

\section{Antonio Pérez Lasheras}

\section{OpenEdition}

\section{Journals}

Edición electrónica

URL: http://journals.openedition.org/bulletinhispanique/321

DOI: 10.4000/bulletinhispanique.321

ISSN: 1775-3821

Editor

Presses universitaires de Bordeaux

Edición impresa

Fecha de publicación: 1 diciembre 2007

Paginación: 545-587

ISBN: 978-2-85276-096-7

ISSN: 0007-4640

Referencia electrónica

Antonio Pérez Lasheras, «La literatura española en la Agudeza de Gracián », Bulletin hispanique [En línea], 109-2 | 2007, Publicado el 01 diciembre 2011, consultado el 01 mayo 2019. URL : http:// journals.openedition.org/bulletinhispanique/321 ; DOI : 10.4000/bulletinhispanique.321 


\title{
La literatura española en la Agudeza de Gracián
}

\author{
Antonio PÉrez Lasheras \\ Universidad de Zaragoza - Espagne
}

Cet article a pour objet l'étude de la littérature espagnole telle qu'elle apparaît dans la Agudeza de Gracián, dans le propos de fournir des éléments susceptibles d'éclairer son propre parnasse. A cet effet, est joint un dictionnaire des noms et des concepts jugés significatifs, assortis de leur définition dans l'ouvre.

Este artículo estudia la literatura española incluida en la Agudeza de Gracián, con el propósito de proporcionar datos para analizar con una perspectiva suficiente su peculiar parnaso. Para ello, se ha incluido un diccionario de nombres y conceptos que se han considerado significativos con su definición en la obra.

This article studies Spanish Literature as it is revealed in the Agudeza by Gracian, in order to provide elements likely to light its own Parnassus. To this end, it is completed with a dictionary of the names and concepts considered significant, with their definition in this work.

Mots-clés : Gracián - Agudeza y arte de ingenio - XVII - Conceptisme - Anthologie - Parnasse.

T A Agudeza y arte de ingenio es una de las obras más complejas del Siglo de oro de la literatura espańola. Esta complejidad afecta, incluso, a su esencia, ya que no sabemos qué pretendió escribir Gracián ; acercarse a esta intención nos ayudaría a saber algo más de la obra.

$B H i$, Tome 109, n² 2 - décembre 2007 - p. 545 à 587. 
Como se ha comentado repetidamente, Agudeza y arte de ingenio constituye una verdadera antología de textos -literarios y no literarios- que se incluyen en la obra como modelos de imitación y como ejemplos paradigmáticos en los que el lector ha de aprehender, intuitivamente, la esencia de lo agudo. En un momento de su vida, Gracián reconoce que tiene un «hartazgo de coplas» ${ }^{1}$. Es significativo, en este aspecto, que Gracián sea, algunos años después de la publicación de la Agudeza, el inspirador de una de las pocas antologías de poesía de los Siglos de Oro, las Poesías varias de grandes ingenios de José Alfay (Zaragoza, 1654) 2. Seguramente, en los años de confección del Arte y de su ampliación en la Agudeza (desde 1636, más o menos, a 1648), nuestro jesuita podría haber mostrado también su «hartazgo».

Existen algunas circunstancias que nos pueden ayudar en nuestro intento. En primer lugar, se trata de una obra que el autor reescribió completamente y de la que se publicaron dos versiones muy diferentes en seis años (1642, la primera, y 1648, la segunda), con títulos distintos: Arte de ingenio. Tratado de la agudeza y Agudeza y arte de ingenio. En este sentido, uno de los problemas de esta obra es que no tiene tradición en la Literatura española y que, por lo tanto, no puede encuadrarse en un género concreto ni en una línea determinada.

Analicemos primero lo que pretende Gracián en su obra. Lo haremos atendiendo a las primeras páginas de la misma, principalmente a los elementos paratextuales (título y prólogo) y a los tres primeros discursos. Ya el título nos indica que se propone realizar un tratado sobre el ingenio, que vendría a ser, según nos explica en la introducción «Al Letor», la «agudeza en arte». Por consiguiente, agudeza e ingenio parecen términos intercambiables. Sin embargo, podría matizarse algo más: la agudeza es sólo obra del ingenio, y lo que se propone es dotarla de arte, es decir, de reglas, extraídas a partir de la observación (reflexión y definición). Hasta ahora -viene a decirnosla agudeza producía frutos surgidos del ingenio - de la naturaleza de cada escritor-, sólo la retórica analizaba algunos instrumentos para expresarlos cultamente, por eso pretende clasificar los modos en que se produce la agudeza y dar ejemplos dignos de imitación; ejemplos variados, porque hay que atender a la variedad de los frutos del ingenio ${ }^{3}$. El ingenio será, pues, la

1. Aprobación de Baltasar Gracián a la obra de Francisco de la Torre y Sevil, Entretenimiento de las musas en esta nueva baraxa de versos (Zaragoza, Juan de Ibar, 1654). Hay edición moderna de Manuel Alvar, Edición y estudio del Entretenimiento de las musas de don Francisco de la Torre y Sevil (Valencia, Universitat, 1987, p. 79).

2. Ed. moderna incompleta de J. M. Blecua, Zaragoza, Institución «Fernando el Católico», 1946. Vide Rozas [1986].

3. «Válese la agudeza de los tropos y figuras retóricas, como de instrumentos para exprimir 
facultad para producir obras del entendimiento; la agudeza será el efecto del mismo y el concepto vendría a ser el resultado, la expresión de dicho acto.

Gracián quiere escribir su tratado partiendo de la observación y la reflexión para llegar a definir la agudeza, si fuera posible. Todo el primer discurso y parte del segundo tratan de defender la necesidad de sistematizarla, la de reducirla por medio de un método inductivo-analítico ${ }^{4}$.

El discurso segundo se dedicará a la definición y al objeto de la agudeza, a pesar de dudar de este intento: «Es este ser uno de aquellos que son más conocidos a bulto, y menos a precisión, déjase percibir, no definir; lo que para los ojos la hermosura, y para los oídos la consonancia, eso es para el entendimiento el concepto.» Es ahora cuando esbozará la tan conocida definición del concepto: «Consiste, pues, este artificio conceptuoso en una primorosa concordancia, en una armónica correlación entre dos o tres cognoscibles extremos, expresada por un acto del entendimiento"; se trata de «un acto del entendimiento que exprime la correspondencia que se halla entre los objetos» ${ }^{5}$. Poco antes había intentado definir el objeto de la agudeza, que no es otro que conjugar belleza y verdad o, si se quiere, expresar la belleza de la verdad o la verdad de la belleza, ya que «No se contenta el ingenio con sola la verdad, como el juicio, sino que aspira a la hermosura». Casi al final de la obra, vuelve a referirse a la Verdad, que ya no resulta una verdad clara y evidente, sino que se esconde ; por ello, acude a una larga alegoría [LV, LVI].

El tercer discurso trata de la variedad -fundamento primordial de la tesis de Gracián- ${ }^{6}$ y comienza las diferentes clasificaciones de la agudeza.

cultamente sus concetos, pero contiénense ellos a la raya de fundamentos materiales de la sutileza, y cuando más, de adornos del pensamiento.» («Al Letor»); «Son los tropos y figuras retóricas materia y como fundamento para que sobre ellos levante sus primores la agudeza, y lo que la retórica tiene por formalidad, esta nuestra arte por materia sobre que echa el esmalte de su artificio.» [XX]. Citaré por el capítulo. Utilizo las ed. de Correa (1967, reeds. de 1987, 2001) y Peralta, Ayala y Andreu (2004).

4. «No pasaban a observarla, con que no se halla reflexión, cuanto menos definición». «Eran los conceptos hijos más del esfuerzo de la mente que del artificio». «...salían a luz sin magisterio. La imitación suplía al arte [...] Pero no se puede negar arte donde reina tanto la dificultad. Ármase con reglas un silogismo; fórjese, pues, con ellas un concepto. Mendiga dirección todo artificio, cuanto más el que consiste en sutileza del ingenio».

5. «...cualquiera sentencia es concepto, porque esencialmente es acto del discurso una verdad sublime, recóndita y prudente, pero las que son propias de esta arte de agudeza, son aquellas que se sacan de la ocasión y les da pie alguna circunstancia especial, de modo que no son sentencias generales, sino muy especiales, glosando alguna rara contingencia por ella.» [XXIX]

6. Aurora Egido, «La variedad en la Agudeza de Baltasar Gracián», en Fronteras de la poesía en el barroco, Barcelona, Crítica, 1990, pp. 241-258. Incluido también en La rosa del silencio. 
Tras realizar uno de los primeros elogios de la variedad como fuente de hermosura, comienza las divisiones: agudeza de perspicacia y de artificio. Su tratado sólo atenderá a la segunda, dado que la primera es natural y, por tanto, espontánea. Estamos ante la divisisón ars / ingenium, ars / natura tan propia de las discusiones literarias de la época. O, dicho de manera llana, la eterna pregunta de si el poeta nace o se hace (en este caso aplicado a la agudeza). Evidentemente, sólo lo que puede hacerse precisa de reglas. La agudeza de artificio será, pues, el objeto de su estudio, y ésta se divide en agudeza de concepto, agudeza verbal y agudeza de acción. Con ejemplos de las tres exornará su tratado ${ }^{7}$.

Pero la propuesta estética de Gracián debe analizarse y valorarse, además, desde su apreciación de la literatura de la época y a través de sus propias palabras, con las que defiende la dificultad con argumentos muy similares a los que utilizó Góngora en su conocida carta ${ }^{8}$, utilizando el símil agustiniano de la corteza y el meollo?

Lo curioso es que, al hablar de estilos, Gracián considera principalmente los estilos artificioso y aliñado, y Góngora consta dentro de este último. Para Gracián toda la literatura barroca es conceptista. Es, pues, evidente, que la visión del jesuita no coincide en absoluto con la que tenemos hoy. Será en la consideración de los diferentes autores donde observaremos sus preferencias.

Los ejemplos que Gracián utiliza para mostrar los distintos tipos de agudeza son literarios y no literarios. Entre estos últimos, se citan anécdotas

Estudios sobre Gracián, Madrid, Alianza, 1996.

7. A partir de aquí, va seccionando el objeto de su estudio: dentro de la agudeza conceptual, según el tipo de relación (positiva o negativa) entre los términos correlatos (agudeza de correspondencia o conformidad y agudeza de contrariedad o discordancia); agudeza pura y agudeza mixta; incompleja y compuesta, etc. Dentro de la agudeza verbal, tendremos todo tipo de juegos verbales (dilogías, antanaclasis, disociación, políptote, derivación, etc.), definidos según los tropos retóricos. Y así hasta completar las diferentes especies.

8. Carta de don Luis de Góngora en respuesta de la que le escribieron, fechada el 30 de septiembre de 1613, apud Antonio Carreira, ed., Epistolario completo, Zaragoza, Libros Pórtico-Sociedad Suiza de Estudios Hispánicos, 1999, n 1, p. 1; antes en Juan e Isabel Millé y Jiménez, eds., Luis de Góngora y Argote, Obras Completas, Madrid, Aguilar, 1972, 6a ed., p. 895 , con algunas variantes.

9. «...quien dice misterio, dice preñez, verdad escondida y recóndita, y toda noticia que cuesta, es más estimada y gustosa» [VI]; «Cuanto más escondida la razón, y que cuesta más, hace más estimado el concepto, despiértase con el reparo la atención, solicítase la curiosidad, luego lo exquisito de la solución desempeña sazonadamente el misterio» [VI]; «La verdad, cuanto más dificultosa, es más agradable, y el conocimiento que cuesta, es más estimado» [VII]; «Preñado ha de ser el verbo, no hinchado» [LX]. 
atribuidas a los grandes hombres de la antigüedad y otras modernas; las hay apócrifas, basadas en las palabras (dichos) y otros en actos (hechos). Dichos y hechos agudos. También encontramos numerosos ejemplos extraídos de predicadores y autores religiosos. Destacan, en este aspecto, la gran cantidad de profesos de la Compañía de Jesús. También resulta curioso observar que cita a gran cantidad de miembros de su propia familia, atribuyéndose, de esta manera, una predisposición congénita a la agudeza. Incluso cabría señalar la presencia de algunos predicadores y autores declaradamente contrarios a los intereses de la Compañía o enemigos personales.

En cuanto a la literatura, la Agudeza puede servirnos como referencia de lo que se conocía en tiempos de Gracián de la literatura anterior, tanto de la española como de la latina y la europea. Supone una perspectiva, muy particular si se quiere, pero de un lector real en un tiempo concreto; de un lector que no sólo lee, sino que interpreta críticamente e, incluso, propone modelos para ser imitados. Atendiendo al muestrario de autores citados por Gracián, hay que reconocer que excede con creces las expectativas lectoras de un hombre culto de su época: textos de muchos de los autores de la antigüedad (historiadores y literatos), especialmente latinos; textos modernos en latín, italiano, portugués y español. Entre los autores españoles, Gracián diferencia entre antiguos y modernos ${ }^{10}$, considerando antiguos a los poetas de cancionero e, incluso, a otros, como Gregorio Silvestre, que escribieron a la manera cortesana. En general, consideraba antiguos a todos los autores anteriores a su siglo. Habría también que destacar las ausencias, que, en cuanto a la prosa literaria, es casi absoluta. Puede llamarnos la atención el hecho de que Gracián no cite en ningún momento ninguna de las preceptivas literarias anteriores, ni españolas ni italianas, salvo el Arte poética de Juan Díaz Rengifo (1592) y no precisamente como apoyo teórico, sino simplemente para citar un palíndromo. Ni Alfonso Carballo, ni Francisco Cascales, ni Francisco López Pinciano se citan ni una sola vez, al igual que ocurre con Minturno o Robortello, aunque hay más de una concurrencia.

El dicho agudo, sentado, en gran medida, en la unión de lo disímil, vendría a poner coto a un fenómeno literario que se encuentra, en ese momento de escritura de la Agudeza, en pleno apogeo, aunque ya hayan pasado los grandes creadores que la cultivaron. En efecto, Góngora, Lope y Quevedo -junto a Rufo, Melchor de Santa Cruz o los hermanos Argensolaproporcionan las fuentes más destacadas del exemplario de Gracián. Entre los antiguos, evidentemente, destaca Marcial, de quien introduce las «ingeniosas»

10. Vide Pelegrin, 1987. 
traducciones de su amigo el canónigo oscense Manuel de Salinas, presencia que ha sido destacada por la crítica, aunque no siempre con criterios uniformes ${ }^{11}$. También se ha señalado la gran ausencia: Cervantes, que choca en un erudito y fino crítico como, sin duda, es el jesuita aragonés y que no se explica sino como un "olvido voluntario» ${ }^{12}$.

En la visión que Gracián tiene de la literatura hay elementos que resultan muy curiosos, por cuanto nos indican, por un lado, el estado de la cuestión de un concepto que todavía no existe, pero que, como diría el propio Gracián, querría ser. Quiero decir que existe una clara conciencia de lo que es y lo que representa la literatura española, aunque el concepto de esta historia no es el que ahora tenemos. En todos los casos, lo que se conoce es lo único que puede consignarse y, por consiguiente, referido en una prelación y constitutivo de conformar el canon. Así, por ejemplo, el conocimiento que tiene Gracián de la literatura medieval es muy limitado y se reduce a aquello que había pasado a la letra impresa. Es la imprenta, por lo tanto, un elemento fundamental en la conformación del canon.

A grandes rasgos podemos indicar que, a mi modo de ver, existen cinco líneas que vertebran la visión que Gracián tiene de la literatura.

En primer lugar, habría que decir que pretende una continuidad que agrupa desde la literatura clásica greco-latina a la contemporánea a su tiempo, aunque lo cierto es que la presencia de autores y obras de la literatura española es abrumadora comparada con la de otras tradiciones, pero también tenemos menciones de obras de la literatura italiana, portuguesa o francesa.

La segunda es la presencia conjunta de literatos y oradores, igualando retórica y poética, algo muy común en esta época.

La tercera es la presencia de aragoneses, de los que siempre hace mención de su proximidad, más emocional que física, con la inclusión casi fija y necesaria del posesivo «nuestro», que funciona a manera de dativo ético. Sobre ellos, al hablar de Verzosa, comenta: «El logro de este gran autor, con otros muchos de los antiguos españoles, especialmente de nuestros aragoneses, en número y calidad insignes, de quienes he tenido colmada fruición, si antes, ni aun noticia, reconozco y estimaré siempre al copioso y culto museo de

11. Desde los primeros trabajos de Giulian [1930] o Parga [1930], hasta los de Cabré [1963-1965], Laurens [1980], Cristóbal [1987], Muñoz García de Iturróspide [1995], y los, mucho más exhaustivos de P. Cuevas [2000]. En Agudeza se incluyen 7 traducciones más de Salinas de epigramas de Marcial, con respecto al Arte.

12. Peralta, 1986. Sobre Salinas, su vinculación con Gracián y sus traducciones, son definitivas las investigaciones de Pablo Cuevas en su tesis doctoral [2000] y su edición de la poesía de este autor [2006]. 
nuestro mayor amigo don Vicencio Juan de Lastanosa, benemérito universal de todo lo curioso, selecto, gustoso, en libros, monedas, estatuas, piedras, antigüedades, pinturas, flores, y en una palabra, su casa es un emporio de la más agradable y curiosa variedad.» [XII]

La cuarta y la quinta, que podrían considerarse casi como las conclusiones, podrían resumirse en dos premisas: la agudeza, el ingenio, es, por una parte, una característica intrínseca, casi innata, hoy diríamos que genética o congénita, que se hereda y que, por consiguiente, es propia de algunos pueblos y ajena a otros; es decir, propia de la natura. El caso más curioso en este aspecto será la mención de varios miembros de su propia familia, como buscando una tradición peculiar de la que él mismo es partícipe ${ }^{13}$. Pero, al mismo tiempo, y por otra parte, la agudeza es también una técnica que se puede aprender, con arte, es decir, con estudio y aplicación. Como ejemplo de este punto tendremos una especial presencia de miembros de la Compañía de Jesús, dando a significar que, por una especial educación, también la agudeza es connatural a los miembros de esta orden religiosa.

Si nos referimos ya a autores u obras concretos, destaca la atención de la crítica por alguno de ellos. Sería el caso de Don Juan Manuel y su obra El conde Lucanor ${ }^{14}$. Gracián dispuso de un instrumento muy especial: la edición de la obra del Infante Don Juan Manuel realizada por Gonzalo Argote de Molina, publicada en 1575 y reeditada en $1642{ }^{15}$. El hecho de que en la primera redacción de la obra, el Arte, no aparezca mencionada esta obra nos puede inducir a pensar que Gracián utilizó la edición más cercana a la reelaboración de Agudeza. Su interés por ella es muy subido ${ }^{16}$. La novedad

13. Así los siguientes: Gracián de la Madre de Dios, Reimundo: «gran religioso y docto, más corona mía que hermano» $[\mathrm{XX}]$. Gracián, Felipe: «gloria y corona mía más que hermano, eminente teólogo, como quien ha profesado la teología en las mejores cátedras de su sagrada religión, gran predicador, con plausibilidad en lo sutil y bien discurrido.» [XX]. Gracián, Francisco: «mi padre, hombre de profundo juicio y muy noticioso» [XXIII]. Gracián, Reimundo: «mi primo» [XXXI].

14. Buceta [1924], Pelegrin [1988], Orotbig [1992] y Hinz [1999].

15. «varón insigne en noticias, erudición, historia, y de profundo juicio.» [XXVII].

16. «digno de la librería délfica» [XXIII]; «el nunca bien apreciado libro de El Conde Lucanor, en que redujo la filosofía moral a gustosísimos cuentos; bástale para encomio haberlo ilustrado con notas y advertencias, e impreso modernamente Gonzalo Argote de Molina, varón insigne en noticias, erudición, historia, y de profundo juicio». [XXVII]; «siempre agradable, aunque siete veces se lea». [XXXV]. Sobre su autor, el Infante don Juan Manuel, comenta: «El que fue inventivo, prudente y muy sazonado fue el excelentísimo príncipe Don Manuel, hijo del infante Don Manuel y nieto del rey Don Fernando el Santo. Este sabio príncipe puso la moral enseñanza de la prudencia y de la sagacidad en algunas historias, parte verdaderas, parte fingidas, y compuso aquel erudito, magistral y entretenido libro, titulado 
radica en que estamos ante una de las primeras reivindicaciones de esta obra, al menos hasta donde se me alcanza. Hay que señalar que Gracián la cita en seis ocasiones muy elogiosamente y que se incluyen extensamente cuatro exempla y uno se resume. Como ha estudiado Pelegrin [1988], cita tan sólo ejemplos de la primera parte (libro primero), es decir, de los exiemplos o apólogos. Y resulta curioso porque la segunda parte (libros 2, 3 y 4) contiene los proverbios, que podrían haberle servido como claro modelo de conceptismo, pero esta segunda parte no aparece en la edición de Argote de Molina, que aprovecha la ocasión para introducir su «Discurso sobre la poesía castellana» o un diccionario de voces antiguas. Pelegrin habla de otro «olvido voluntario», Hinz de desconocimiento de las otras partes del libro.

Otra de las obras que quiero significar por lo curioso y sorprendente de su afirmación es La Celestina, obra que considera escrita por un aragonés: «el encubierto aragonés en su ingeniosísima Tragicomedia de Calixto y Melibea» [LVI]. La confusión puede deberse a que la edición definitiva de la obra, la que lleva el título consignado, fue impresa en Zaragoza a comienzos del siglo XVI (concretamente, en 1507), pero resulta más curioso pensar que esta tesis ha vuelto a ser enunciada por algunos críticos en la segunda mitad del siglo $\mathrm{xx}$, haciendo, incluso, constar el recorrido de la ciudad, que sería Zaragoza y no Salamanca ${ }^{17}$.

Finalmente, dentro de la literatura medieval, la poesía de cancionero también se encuentra bien representada en la Agudeza, como ha mencionado la crítica ${ }^{18}$, a través de varios ejemplos extraídos del Cancionero General de Hernando del Castillo (Valencia, 1511). Es más, los discursos XXIV y XXV, en los que se explica la agudeza por paradoja y juegos de contrarios ${ }^{19}$, están

El Conde Lucanon». [XXIII]; «El príncipe Don Manuel trae algunas [fábulas] selectas y bien fingidas, pero entre todas, aquella fábula de la Vulpeja, cuando se fingió muerta...» [LVI]; «Fue único en este género [cuentos] el príncipe Don Manuel, en su nunca debidamente alabado libro de El Conde Lucanor, entretejido de varias historias, cuentos, ejemplos, chistes y fábulas, que entretenidamente enseñan». [LVII].

17. Esta tesis ha sido defendida por diversos autores a lo largo del pasado siglo, pero recientemente, vuelve a ella José Guillermo García Valdecasas, en su obra La adulteración de la Celestina (Madrid, Castalia, 2000).

18. Battesti-Pelegrin, 1985; Casas Rigall, 1995.

19. «De los conceptos por una propuesta extravagante, y de la razón que se da de la paradoja», y "De los conceptos en que se pone algún dicho o hecho disonante, y se da la equivalente y sutil razón». Aparecen Lope de Sosa, Escribá, Pedro de Cartagena, Carlos de Guevara, Nicolás Núnez, Garci Sánchez de Badajoz, Diego de Castro, Diego de San Pedro, Conde de Oliva, Juan Fernández de Heredia, Soria, Juan de Tapia, Diego López de Haro, Diego de Velasco, Alonso de Córdoba, Jorge Manrique, Diego de San Pedro, Duque de Medina Sidonia. Se cita además el principio de las Coplas a la muerte de su padre, de Manrique 
plagados de ejemplos tomados de este tipo de poesía, normalmente citados en una redondilla.

En líneas generales, los sintagmas empleados para ponderar a la mayor parte de los autores y sus obras son muy parecidos: «agudo», «agudísimo», «ingenioso», "conceptuoso», etc. Pero puede hacerse alguna diferenciación, como veremos con los poetas barrocos, los que, de alguna forma, configuran el Parnaso graciano. En este sentido, son significativas la presencia de Lope de Vega y las ponderaciones que le hace el autor, por una parte, y mencionar las diferencias entre las dos versiones de la obra (Arte de ingenio, 1642, frente a Agudeza y arte de ingenio, 1648), por otra.

Lope de Vega es, sin duda, uno de los autores más mencionados en $L a$ Agudeza. Aparece nombrado en 38 ocasiones. De él se citan 5 romances, 1 canción, 21 sonetos (20 completos), 5 composiciones de arte menor y las siguientes obras: El dómine Lucas, El villano en su rincón, La dama boba, Los melindres de Belisa y las Novelas a Marcia Leonarda. Sin embargo, hay que observar que las calificaciones con que aparece el Fénix son bastante tibias. Normalmente, se le elogia por sus cualidades, por su ingenio, por su naturaleza, pero no por su arte, en la línea que ya marcara, años antes, Góngora ("potro es gallardo, mas va sin freno»). También podemos notar que los elogios son menos tópicos y más comprometidos conforme avanza la obra; de manera que parece que el propio Gracián fuera refrenando y perfilando sus ponderaciones. A Lope se le denomina «célebre» (III), «prodigioso» (IV), "abundante» $(\mathrm{V})$, "plausible», «ingenioso» $(\mathrm{V})$, «fruto de la más fértil vega» (VII), «fecundo y facundo» (XX), «eminente» (XXXVII), «el cisne de la más fecunda vega» (XLV), "universal» (LV). Pero a menudo acompańan a estos elogios una matización que siempre alude a la abundancia de su producción, a la falta de artificio.

En lo que se refiere a las modificaciones entre el Arte y la Agudeza, hay que recordar que la inclusión de Garcilaso (que no aparece en $A r t e)^{20}$, o la mayor presencia de los hermanos Argensola (en el Arte sólo aparece Bartolomé en 4 ocasiones $)^{21}$ o Lope de Vega (6 veces en Arte) se debe, en gran medida, al influjo de sus contertulios y a la predilección del grupo oscense, en especial de Manuel Salinas, por el estilo llano y conceptista. El peso del conceptismo poético, en el Arte, se concentra, además de en la poesía de Góngora (con 48 menciones), en la poesía renacentista: Jorge de Montemayor (21 citas,

[XLII]; Juan de Mena aparece con un enigma, Alonso de Madrigal y poco más.

20. Navarro, 1986.

21. Blecua, 1950. 
10 de ellas de la Diana) y Luis de Camoens (18) ${ }^{22}$, además de alguna concesión "cortesana», como la de Antonio Hurtado de Mendoza (9). En la poesía latina, la proporción es similar: escasa presencia de Horacio (3), de Virgilio (2), Ovidio y Terencio (1), frente al triunfo absoluto de Marcial (46 menciones) o de Ausonio (6), autores ambos postclásicos ${ }^{23}$. En la Agudeza las cosas cambian considerablemente: hay más de cien autores de los Siglos de Oro incluidos y comentados por Gracián; aumenta la presencia de Góngora (77 menciones) ${ }^{24}$, que es el autor más citado por sus obras originales (sólo superado por Manuel Salinas, autor de la mayoría de las traducciones que se incluyen: le supera con 84 apariciones). De esta manera, Góngora y Marcial copan los laureles de la Agudeza. De él tenemos los más elevados elogios, aunque puede dar la impresión de que Gracián se contuviera a la hora de adjetivar a su admirado poeta ${ }^{25}$.

Se ha mencionado en muchas ocasiones la mayor presencia de Góngora, frente a Lope de Vega o a Quevedo (que apenas aparece una decena de veces), por ejemplo, pero también convendría saber qué Góngora es el que aparece. De Góngora se citan sobre todo sonetos (22, 20 reproducidos íntegramente) y romances (20, reproducidos parcialmente); se citan además 3 letrillas, 1 canción, 9 veces Las firmezas de Isabela, 3 el Polifemo, una las Soledades.

Es hora de ir concluyendo. Es evidente que la Agudeza supone una visión característica y privilegiada de la literatura, especialmente de la literatura española que, aunque no es la única, es la más ampliamente representada en la obra. Son muchas las afirmaciones, las presencias, los comentarios o las

22. Larsen, 1981.

23. Cuevas, 2000, I, 72-74, y 2006.

24. Vide P. M. Costa, 1977; Dehennin, 1980; Poggi, 1986; Carreño, 1989; M. Blanco, 1994; Woods, 1995.

25. Habla de «un gran concepto» [IV], de «extremada sutileza» [V], «amorosa emulación» [IX] o "extremado soneto» [IX], «elegante y premiado" [X], "sublime epigrama» [XXXIII]; «ingenioso» [VI], «en su limada fábula del Polifemo» [XIX], «con primor ingenioso» [XXVII], «su única Isabela, que valió por mil» [XLII], "con mucha arte» [XLIV], «en quien toda sutileza cabe» [XLIV], «en su aliñado, elocuente y recóndito poema del Polifemo» [XLVIII]. En fin, «tan gran poeta» $[X X X I I]$, aunque, a veces también es capaz de ironizar: «en uno de sus romances, y no el peor» $[\mathrm{XV}]$; otras veces, el elogio es más extenso: «Fue este culto poeta cisne en los concentos, águila en los conceptos; en toda especie de agudeza eminente, pero en ésta de contraposiciones consistió el triunfo de su grande ingenio» [V]; «El Benjamín de Córdoba, don Luis de Góngora, es hasta hoy última corona de su patria» [LXI]; [estilo aliñado] «lo remontó a su mayor punto don Luis de Góngora, especialmente en su Polifemo y Soledades. Algunos le han querido seguir, como Ícaro a Dédalo; cógenle algunas palabras de las más sonoras, y aun frases de las más sobresalientes [...], incúlcalas muchas veces de modo que a cuatro o seis voces reducen su cultura» [LXII]. 
ausencias que nos llaman poderosamente la atención. Sobre las ausencias, la más famosa y archiconocida es la de Cervantes y su obra maestra, que no aparecen ni una sola vez, en una pirueta que Peralta definió como de "olvido voluntario»; pero esto no dejaría de ser anecdótico de no mediar otra circunstancia: la elevación del Guzmán de Alfarache a la cima de la prosa poética espańola. Tanto la obra, a la que Gracián se refiere por su subtítulo (Atalaya de la vida humana), como su autor, Mateo Alemán (sobre quien deja caer alguna duda de que fuera su verdadero autor), alcanzan los más elevados elogios: "Por otro encarecimiento explica con mucha erudición y sazonado estilo» [XXVII]; «discreto» [XLIII]; "célebre» [LV]; "Aunque de sujeto humilde, Mateo Alemán, o el que fue el verdadero autor de la Atalaya de la vida humana, fue tan superior en el artificio y estilo, que abarcó en sí la invención griega, la elocuencia italiana, la erudición francesa y la agudeza española» [LVI]; "Mateo Alemán, con su gustoso estilo» [LVI]; "por eso ha sido tan leído y celebrado Mateo Alemán, que a gusto de muchos y entendidos es el mejor y más clásico español» [LXII].

Algún dato más podríamos recoger, aunque sea a manera de meros apuntes. Sorprende la escasa presencia de Petrarca, pero también de muchos poetas del siglo XVI, como Fernando de Herrera o Fray Luis de León, que chocan con la presencia de otros que en el canon actual cobran menos valor, como Montemayor o Silvestre, por ejemplo. También podría sorprender la presencia de un poeta y dramaturgo como Antonio Hurtado de Mendoza, sólo comprensible desde la intención "cortesana» de la primera versión de la obra.

En fin, se puede observar el intento graciano de crear una tradición de agudeza aragonesa (se citan más de veinticinco poetas aragoneses y más de cincuenta personajes de esta procedencia, marcándola casi siempre con un peculiar nuestro), que parte de Marcial y cuyo mayor representante en su siglo sería Bartolomé Leonardo de Argensola. Habría que analizar la importancia que Gracián da a la imagen como fuente de conocimiento y el reconocimiento que se hace de Alciato, de quien se citan hasta 17 emblemas; cotejar las dos antologías de la poesía áurea (Las Flores de Poetas Ilustres, de Pedro de Espinosa, 1605, y las Poesias varias, de Alfay, 1654), como fuentes poéticas del bilbilitano; ilustrar la presencia de otros grupos además del aragonés, como el valenciano o el portugués, etc. Pero quedará todo ello para otro momento.

Para terminar, incluyo una selección de autores citados por Gracián en La Agudeza, centrada principalmente en los españoles, con la definición con que se refiere a ellos el jesuita aragonés. Este listado no pretende ser exhaustivo, aunque si representativo para lo que se ha pretendido en este trabajo. 


\section{ÍNDICE DE AUTORES CITADOS EN LA AGUDEZA ${ }^{26}$}

Abarca de Bolea, Ana Francisca: «la muy noble e ilustre señora dońa Ana de Bolea, religiosa bernarda, en el Real Monasterio de Casvas, en Aragón; tía del marqués de Torres, compitiéndose la nobleza, la virtud y su raro ingenio, heredado del insigne y erudito don Martín de Bolea, su padre» [XXXI].

Alcázar, Baltasar de: «Fue donoso en ellos» [equívocos] [XXXIII].

Alciato, Andreas: "prudente y no menos ingenioso" [VI]; "preñado emblema» [XII]; «el filósofo en verso» [XIX]; «que no perdonaba su gran ingenio a género alguno de sutileza» [XXI]; «el ingenioso» [XXXVI]; «atento» [XL].

Alberite, Padre Jerónimo: «de la Compañía de Jesús, aragonés, ornamento de la ciudad de Borja, su patria, eminente predicador, así en las cosas como en decirlas» [LII].

Andrés de Uztarroz, Baltasar: «benemérito de todas las buenas letras, pero en las matemáticas eminente» [XXVIII].

Andrés de Uztarroz, Juan Francisco: «cronista del reino de Aragón, por aplauso de sus Cortes generales y autoridad de Su Mejestad, noticioso, anticuario, elegante humanista, culto poeta, grave jurisconsulto, juicioso historiador; porque no le falte a este Reino siempre un Jerónimo Zurita; cuya grata memoria nos la renueva.» [XIV]; "con igual eminencia en el verso que en la prosa» [XIV]; «no menos ingenioso en la poesía que cuerdo en la historia» [XXXI]; «ingenioso epigrama del doctor...» [LII].

Andrés, Jerónimo: «monje del Real Convento de San Juan de la Peña, tan eminente en el púlpito como en la cátedra» [LIV].

Aquino, Santo Tomás de: «el autor de los autores» [VII].

Aragoneses: «El logro de este gran autor [Verzosa], con otros muchos de los antiguos españoles, especialmente de nuestros aragoneses, en número y calidad insignes, de quienes he tenido colmada fruición, si antes, ni aun noticia, reconozco y estimaré siempre al copioso y culto museo de nuestro mayor amigo don Vicencio Juan de Lastanosa, benemérito universal de todo lo curioso, selecto, gustoso, en libros, monedas, estatuas, piedras, antigüedades, pinturas, flores, y en una palabra, su casa es un emporio de la más agradable y curiosa variedad.» [XII].

Arguijo, Juan de: «cabal soneto de..., uno de los grandes ingenios de España, que atiende más a la profundidad y gravedad del concepto que a la verbosa altanería» [XLIV]; «el siempre moral y sentencioso» [XLIX]; «este profundo y significativo epigrama de don...» [LIX].

Ávila, Pedro de: «fue feliz en las trazas, pero aquella de Las fullerías de amor fue la más plausible que se ha oído» [XLV].

Azaola, Juan: «el docto..., bilbilitano» [XXXIV].

Babia, Luis de: "Escribe el doctor Babia, con estilo claro, pero muy terso y elegante» [LXII].

26. El número romano corresponde al capítulo. 
Baeza, Padre Diego de: «de la Compañía de Jesús, aquel gran maestro del discurrir, fuente perene de conceptos y agudezas, lo de la Fénix, que muere entre olorosos y lucidos incendios, muere entre encendidas llamas, para resucitar luego, gallarda, vitoriosa y triunfante.» [LIX]; «Ladéasele el Padre Diego de Baeza, prestando luz a tantos de su séquito, compiten en celada la cultura y la agudeza» [LXI].

Bocángel, Gabriel: «el conceptuosamente bizarro» [XLII].

Boil, Padre Francisco: «ingenio de los de primera magnitud y único en la acolucia de los discursos» [LIV].

Bolea, Martín de: «su padre [de Ana Abarca de Bolea], cuyas poesías han sido siempre aplaudidas y estimadas» [XXXI].

Cabrera de Córdoba, Luis: «es ya más afectado» [LXII].

Cafarra, Francisco María, duque de Nocera: «virrey que fue y capitán general de Aragón y Navarra, plausible en entrambas naciones por sus grandes prendas de superior entendimiento, indecible agrado, humano trato, galantería con que hechizaba las gentes, y en una palabra, él era universal héroe» [LV].

Calderón de la Barca, Pedro: «merece el inmortal laurel, así como La dama duende, de Calderón» [XLV].

Camoens, Luis de: «el inmortal» [IV]; «célebre» [IV]; «el conceptuoso Camoes» [VI]; «el inmortal Camoes, pero ésta ha sido el blanco de sus aplausos» [XXII]; «el grave y sutil» [XXIV]; «el sutilísimo» [XXXVI]; «El siempre agudo» [XXXVII]; «Añadió a la excepción una extremada contradicción y encarecimiento» [XLIV]; «el celebrado» [LXIII].

Carrillo y Sotomayor, Luis: «el primer culto de España» [III]; «ingenioso» [III]; "profundo y culto» [VIII]; "gran soneto» [IX]; "cuya musa fue siempre bizarra e ingeniosa» [XXII]; «la exprimió por encarecimiento» [LIX]; «culto epigrama de don Luis Carrillo, competido, pues fue el primero, o imitado» [LIX]; "este gran soneto de don...» [LX]; "[estilo aliñado, que tiene más de ingenio que de juicio] Fue Fénix dél, no tanto por primero, pues ya en latín Apuleyo y en el español don Luis Carrillo lo platicaron» [LXII].

Cartagena, Alonso de: "del famoso Cartagena» [XXV] [Cancionero].

Castro Verde, Francisco de: «célebre orador agustiniano... el mayor que ha habido en España» [XXVII]; «el célebre...» [LI].

Castro, Guillén de: "La fuerza de la costumbre, de don Guillén de Castro, por la bizarría del verso y por la invención, merece el inmortal laurel, así como La dama duende, de Calderón» [XLV].

Céspedes, Padre Valentín de: «jesuita y perfecto orador de nuestros tiempos» [XIV].

Colmenares, Diego de: "Con extremado artificio" [VIII].

Cueva, Francisco de la: "pondera conceptuosamente» [IV].

Díaz de Rengifo: «Llenando de heroicos versos estas letras, como lo trae el autor del Arte poética, que fue un padre de la Compañía de Jesús, aunque la sacó en nombre de su hermano Juan Díaz de Rengifo.» [XXXII].

Dicastillo, Miguel: «y más a la generosa humildad, Miguel Discatillo, en su 
grave, ingeniosa y culta Aula de Dios...» «QQué juiciosamente censura la necedad común, con acierto bien especial!» [XXVIII].

Díez, Fray Felipe: «ingeniosísimo franciscano» [XIV].

Escalante, Bernardino de: «los gustosos Diálogos de Escalante, que tratan de arte militar, ricos de escogida y sazonada noticia.» [LVIII].

Escalígero, Julio César: «ingenioso» $[\mathrm{XXI}]$.

Escribá Comendador: «eminente ingenio valenciano» [XXIV].

Esmir, Esteban de: «obispo de Huesca, ejemplar universal de prelados, de doctos y de santos, desempeñando bien el espejo de las armas de su noble y esclarecida prosapia, con igual prudencia que agudeza...» [XXIX].

España: «En España siempre hubo libertad de ingenio, o por gravedad, o por nativa cólera de la nación, que no por falta de inventiva. Sus primeros ingenios, Séneca en lo juicioso y Marcial en lo agudo, fundaron esta opinión, acreditaron este gusto.» [LI].

Esquilache, Príncipe de, Francisco de Borja y Aragón: "príncipe de la Poesía» [III].

Falcón, Jaime Juan: «El Marcial de Valencia» [XIX]; «el más agudo que culto» [XXI]; «este ingenioso epigrama, de aquel que tuvo alas en el ingenio» [LIV].

Fernández de Heredia, Juan: «eminente valenciano» [XXIV].

Florencia, Jerónimo de: «llamado el predicador de los reyes y rey de los predicadores» [XXIII].

Frías, Diego de: «no fríamente, sino con mucha donosidad» [IX]; «El sazonado Frías dijo en su elegante poema de Adonis» [XXXII].

Fuenmayor, Antonio de: «en la Vida de Pio V, digno asunto de tan vigilante pluma» [LXII].

Fuentes, Diego de: «obras del aragonés Diego de Fuentes, célebre poeta por lo conceptuoso» [XXIV]; «nuestro ingenioso aragonés» [XXXIII].

Fúser, Francisco Antonio: «bilbilitano, varón de tan excelente gusto como ingenio» $[\mathrm{LI}]$.

Garcilaso de la Vega: "por su dulzura, facilidad y agudeza» [II]; "cisne de Espańa» $[\mathrm{X}]$; «profundo y grave epigrama» [XXII]; «el más canoro cisne del Tajo» [XXIII]; «bástele su nombre por encomio» $[\mathrm{XXV}]$; «el coronado cisne» $[\mathrm{XXXV}]$; «dulcísimo Garcilaso con una ingeniosa ficción en que hace el argumento por una acordada semejanza» [XXXV]; «famoso» [XL]; «el ideal Garcilaso» [LX]; «esta lisura hace tan ilustre a Garcilaso" [LXII].

Gáriz, Juan de: «veedor general de Navarra, varón de excelente gusto, como lo muestra la gran copia de libros selectos que pueblan sus eruditos camarines, y mucho más ilustra su cortesano entender» [XXIV].

Girón de Rebolledo, Alonso: "agudísimo poeta valenciano»[III].

Góngora y Argote, Luis de: «Esta misma armonía y correlación hizo tan celebrado este soneto de don Luis de Góngora» [IV]; «un gran concepto» [IV]; «Fue este culto poeta cisne en los concentos, águila en los conceptos; en toda especie de agudeza eminente, pero en ésta de contraposiciones consistió el triunfo de su grande 
ingenio» $[\mathrm{V}]$; «extremada sutileza» $[\mathrm{V}]$; «ingenioso» [VI]; «amorosa emulación» [IX]; «extremado soneto» [IX]; «elegante y premiado» [X]; «en uno de sus romances, y no el peor» $[\mathrm{XV}]$; «Excelente careo y concepto plausible, no como aquellos de mucha metafísica y poca subsistencia.» [XV]; «en su limada fábula del Polifemo» [XIX]; "Añadió don Luis de Góngora la hermosa contraposición, ya de lisonja, ya de burla, a la fingida crisi» ["Castillo de San Cervantes»] [XXVI]; "con primor ingenioso» [XXVII]; «tan gran poeta» [XXXII]; «sublime epigrama» [XXXIII]; «Por la disparidad, con sumo artificio, por ser igual de los extremos, agradable pensamiento de don Luis de Góngora» [XXXVI]; "Añadió a la semejanza la grave sentencia don Luis de Góngora» [XXXVII]; «su única Isabela, que valió por mil» [XLII]; «con mucha arte» [XLIV]; «en quien toda sutileza cabe» [XLIV]; «en su aliñado, elocuente y recóndito poema del Polifemo» [XLVIII]; "en aquel gran soneto de don Luis de Góngora al marqués de Castel-Rodrigo, que comienza Árbol de cuyos ramos fortunados, y este otro, de todas maneras relevante, por la pluralidad de conceptos y singularidad de cada uno, pero mucho más por la trabazón y composición que todos ellos hacen.» [LI]; «El Benjamín de Córdoba, don Luis de Góngora, es hasta hoy última corona de su patria" [LXI]; "[estilo alińado] lo remontó a su mayor punto don Luis de Góngora, especialmente en su Polifemo y Soledades. Algunos le han querido seguir, como Ícaro a Dédalo; cógenle algunas palabras de las más sonoras, y aun frases de las más sobresalientes [...], incúlcalas muchas veces de modo que a cuatro o seis voces reducen su cultura» [LXII].

González de Ávila, Gil: «cronista de España, eminente así en lo eclesiástico como en lo secular; sean el desempeño sus obras los tomos, digo, de Las iglesias de España, el del rey de Castilla don Enrique el Enfermo, el gran Gobernador, y el del reinado del rey nuestro señor don Felipe Tercero, ya perfectamente acabado, y el del rey nuestro señor don Felipe el Cuarto, que va continuando, con otros muchos asuntos dignos de su verdad, gravedad y entereza». [L].

Gracián Dantisco: El Galateo Español: «aquel que se pide a Apolo mande sea colocado entre los libros selectos de su biblioteca inmortal» [XXVII]; «ingenioso y docto" [XLIII].

Gudiel, Tomás: «una prudente moralidad y ejemplar sentencia» [XXVIII].

Hernández, Fray Gabriel: «tan grande teólogo como predicador» [XIV].

Herrera, Fernando de: «Ni todo ha de ser jocoso, ni todo amoroso, que tantos sonetos a un asunto liviano, más sentidos que entendidos, en el mismo Petrarca, en el mismo Herrera, empalagan.» [LXIII].

Hurtado de Mendoza, Antonio: «está lleno de conceptos aquel sazonado poema de don Antonio de Mendoza» [III]; "por antonomasia el cisne cortesano»; «su aplaudida comedia» [V]; «sentido y soneto» [XIII]; «aquel emporio de conceptos, la comedia de Querer por sólo querer» [XVIII]; «en su donosísima y siete veces repetida con el mismo agrado, comedia El marido hace mujer, en competencia de El senador de Terencio» [XXVIII]; «en aquel poema, que tuvo estrella, y divina» [XXXVI]; «y es lo mejor que tiene este gran ingenio» [XXXVII]; "aquel gran poema» [XLII]; «Pero quien llegó a lo sumo de la perfección en estos asuntos del ingenio, fueron el 
conceptuoso Villaizán y el sentencioso Mendoza; parece que no se puede decir más de lo que ambos dijeron, ni llegar a más bizarría del verso, preńez de estilo, profundidad de concepto, gravedad de sentencias, invención del enredo, especialmente aquel, en la que intituló Ofender con las finezas, y éste, El marido hace mujer.» [XLV]; "al Mendoza de los ingenios espańoles, le baste para encomio que el mayor gusto del mayor rey, y aun más discreto que monarca, le sublimó al valimiento de su ingenio» [LXI].

Ibáńez de Aoiz, Juan Lorenzo: «moderno cisne del Ebro, en este soneto, bien hablado y bien concepteado" [XXXVI].

Lanuza, Martín Bautista de: «ornamento grande de Zaragoza, su patria, por su nobleza y por su ingenio» [XXXIV].

Lastanosa, Hermenegildo: «Este galante emblema aplicó don..., heredero de su padre, don Vicencio, en todo, hasta en el buen genio, con no menos razón que agudeza» [LIX].

Lastanosa, Juan Orencio de: "canónigo de la iglesia catedral de la ciudad de Huesca, varón de profundo juicio, conocida virtud, mucho saber, perfecto y cabal eclesiástico» [XXVII].

Lastanosa, Vicencio Juan de: «El logro de este gran autor [Verzosa], con otros muchos de los antiguos españoles, especialmente de nuestros aragoneses, en número y calidad insignes, de quienes he tenido colmada fruición, si antes, ni aun noticia, reconozco y estimaré siempre al copioso y culto museo de nuestro mayor amigo don Vicencio Juan de Lastanosa, benemérito universal de todo lo curioso, selecto, gustoso, en libros, monedas, estatuas, piedras, antigüedades, pinturas, flores, y en una palabra, su casa es un emporio de la más agradable y curiosa variedad.» [XII]; «esclarecido caballero en Aragón por su sangre, pues desciende del muy ilustre don Gonbal de Lastanosa, criado muy favorecido del rey Don Jaime el Conquistador, y de don Pedro de Lastanosa, camarero del rey Don Pedro el Cuarto, por su eminente ingenio, adornado de todas las buenas letras. Desempéńame el admirado y celebrado museo de las monedas antigas de Espańa, antes de los romanos y godos, obra exquisita, que dio a la estampa estos ańos, por su buen gusto, como lo decanta el doctor Juan Francisco Andrés, coronista de Aragón, en la descripción elegante, que intitula $D e$ las antigüedades y jardines de su casa. Por su heroico genio, aragonés Mecenas de todos los varones estudiosos, dando vida a sus obras modernas y resucitando las antigas, merecedor insigne de una agradable y agradecida inmortalidad.» [LVII].

Ledesma, Alonso de: «el divino Ledesma» [XXXIII]; "célebre poeta» [LI].

León, Antonio de: "Lisonja agradable al ingenio» [II].

León, Fray Luis de: "grave y no menos ingenioso" $[\mathrm{V}]$; "con grande artificio» [XIV]; «Religiosamente poeta... moral canción» [XXXVI]; "el docto y grave» [XXXVIII].

Leonardo de Argensola, Bartolomé: «laureado soneto» [V]; "gran soneto» [VII]; «Felizmente consiguió su intento» [XII]; «elegante, ingenioso y suave soneto» [XIV]; "gran filósofo en verso» $[\mathrm{XIV}]$; «nuestro aragonés» [XIV]; "que de tan grandes hombres merece la agudeza de Marcial ser ilustrada» [XVIII]; "Con 
excelente modo ponderó Bartolomé Leonardo la pérdida de los estimables trabajos de su gran hermano Lupercio, que los dos fueron sin duda el non plus ultra del Parnaso» [XXI]; "fue único Bartolomé Leonardo, entre muchas graves y de grande enseńanza, imitador en esto del antiguo Horacio.» [XXII]; «juicio y picante epigrama» $[\mathrm{XXIII}]$; «el prudente en verso» [XXIII]; «que fueron los dos mellizos hijos de la más hermosa de las nueve» [XXVII]; «el siempre de veras» [XXXIII]; «el juicioso poeta» [XXXVIII]; "gran ponderador» [XXXIX]; «Todos los sonetos de Bartolomé Leonardo están llenos de profundidad y enseñanzas» [XLIII]; "valiente soneto" [XLIV]; "otro filósofo, también en verso» [LV]; «merece toda estimación ésta [fábula] de Bartolomé Leonardo, así por la moralidad como por la elegante descripción y propiedad de los epítetos» [LVI]; «Úsalos con grande arte y propiedad Bartolomé Leonardo» [LX]; «En lo poético, aunque tan valedor del estilo desafectado, Bartolomé Leonardo, que parecen prosa en consonancia sus versos, fue más preñado su genio que el de Lupercio, su hermano" [LXII].

Leonardo de Argensola, Lupercio: «dulcísimo» [I]; "como se ve en este moral soneto del filósofo de los poetas, Lupercio Leonardo» [XXVIII].

Liñán y Riaza, Pedro: «Realzó lo sentencioso con lo ingenioso nuestro insigne bilbilitano Pedro Liñán, en todas sus obras juicioso, por no desmentirlo de poeta aragonés, y entre más de cien epigramas, todos selectos y conceptuosos, cantó así a un desengańo» [XXVIII]; «nuestro bilbilitano Liñán» [XLVIII].

Lopes de Andrade, Diego: «aquel gran heredero de la sutileza de su gran padre Agustino» [IV]; «conceptuoso» [XIII]; «el ingenioso» [XIV]; «Aquel que entre predicadores mereció la antonomasia de sutil» [XXXI]; «fue heredero de la valentía ingeniosa de su gran padre [San Agustín]» [LXI]; «El estilo del sutil..., agustiniano, es todo delicadeza" [LXII].

López de Mendoza, Diego: «No mostró ser menos conceptuoso y estudioso don Diego López de Mendoza, que con igual sutileza discurrió así» [XXV].

López de Zárate, Francisco: «elegante epigrama del ingenioso Zárate» [II]; «florido ingenio» $[\mathrm{XII}]$; «el culto, aunque no oculto» [XXXVII]; «la exprimió agradablemente el limado Zárate» [XLVIII].

Luna, Álvaro de: «el trágico maestre don Álvaro de Luna en sus Carrozas de las Heroidas" [Libro de las claras e virtuosas mujeres] [LVI].

Marcial, Marco Valerio: «agudísimo» [IV]; "primogénito de la agudeza» [V]; «este prodigio de su agudeza» [VI]; «Ingeniosamente» [VIII]; «nuestro Marcial» [X]; «valiente epigrama» $[\mathrm{XI}]$; «Aquel portentoso ingenio, también de nuestra Bílbilis, y primero entre tantos» $[\mathrm{XX}]$; «este donosísimo epigrama» $[\mathrm{XX}]$; «Fue raro Marcial en este género de agudeza» [Crisis irrisorias»] [XXVII]; "el extremado Marcial» [XXXI]; «el entretenido y salado» [XLIII]; «erudito y dificultoso» [XLIX]; «ingenioso bilbilitano» $[\mathrm{XLIX}]$; «sus eternas obras» $[\mathrm{LX}]$; "Entre los poetas, Marcial fue tan agudo universal, que las musas, leídos sus catorce libros, en lugar del vulgar Finis pusieron Fénix» [LXI].

Marino, Juan Baptista: «No menos dulce que ingenioso» [V]. 
Márquez, Padre Juan: "Como el fue el maestro Márquez, benemérito de la lengua española» [LXII].

Matienzo, Padre Sebastián de: "nuestro grande amigo» [IX]. Lo hace autor de la Heroida Ovidiana, publicada en Pamplona, en 1628, bajo el seudónimo de Sebastián de Alvarado y Alvear.

Mira de Amescua, Antonio: «feliz ingenio» [IX]; «celebrada canción» [XXXV].

Mirto, Plácido: «el plausible don...» [LI]; «elocuentísimo orador de nuestros tiempos» [LIV].

Montemayor, Jorge de: «El afectuoso» $[\mathrm{XXXVI]}$; «Conceptuosamente, como siempre» [L].

Morlanes, Diego: «superior ingenio y universal» [IX]; «en un culto poema» [IX]; «excelente ingenio zaragozano» [L].

Narváez, Hipólita de: «Ingeniosamente discurrió» [XXXVI].

Nebrija, Antonio de: «el famoso Antonio de Nebrija, a quien tanto debieron las letras humanas de Espańa» [XXXIV].

Núñez, Nicolás: "Jugó del retruécano con notable sutileza el ingenioso Núñez» [XXV].

Palafox, Juan de: «obispo meritísimo de la Puebla de los Ángeles. En lo profano fue el primero en este género de inventar el impío Luciano en sus convites y diálogos.» [LVI].

Palmireno, Lorenzo: «el erudito y mucho más que gramático, el juicioso aragonés, que pudo hacer célebre la amena y fértil Alcañiz, su patria, tuvo sabroso ingenio, como se goza en sus libros tan gustosos» [XLIII].

Panigarola, Fray Francisco: «el muy agradable» [LI].

Parada, Pablo de: «tan juicioso como valeroso caballero portugués, Pablo de Parada, el Cid de nuestros tiempos» [XXVIII].

Paravicino, Fray Hortensio: "culto y alińado» [XLIV]; "atento siempre a la perfección de estilo, así en verso como en la prosa» [L]; "el cultamente elocuente» [LI]; «El ingenioso y cultamente elocuente» [LIV]; «el agradable Hortensio: juntó lo ingenioso del pensar con lo bizarro del decir» [LXII].

Pellicer, Josef de: «bien conocido en toda la Europa, por sus raras obras en su misma pluralidad» [XIX]; [La Fénix, de Quevedo] "que con razón aprecia don...» [XLVIII].

Pérez de Montalván, Juan: «tuvo algunas cosas dignas de estimación y excedió en los símiles» [IX]; «en este conceptuoso epigrama» [XXXVI]; «realzó más el estilo, tiene eminencia en los efectos, cometió algunas impropiedades» [XLV].

Pérez, Antonio: "tan favorecido de la fama cuan perseguido de la fortuna» [LXII].

Petrarca, Francisco de: «aplaudida canción» [IV]; «Ni todo ha de ser jocoso, ni todo amoroso, que tantos sonetos a un asunto liviano, más sentidos que entendidos, en el mismo Petrarca, en el mismo Herrera, empalagan.» [LXIII].

Pinto, Padre Diego: "de la Compañía de Jesús, en otra parte ya celebrado» [LIV]. 
Porter y Casanate, Pedro: «El no menos ingenioso que valiente» [XXVIII].

Quevedo, Francisco de: «aquella emulada canción» [IV]; «Por muchos equívocos continuados, don Francisco de Quevedo, que fue el primero en este modo de composición» [XXXIII]; "aquel su tan ingenioso como gustoso poema a la Fénix, que con razón aprecia don Josef Pellicer» [XLVIII].

Ram, Juan Francisco: "Armó desta suerte el doctor..., arcipreste de Morella, ingenio también universal y benemérito de las ciencias sagradas y humanas, una ingeniosa competencia entre los atributos divinos" [LII].

Reyes, Pedro de los: «Grande octava fue ésta, y nunca bastantemente apreciada» [XLIII].

Ribellas, Miguel de: «caballero valenciano» [XIV].

Ribera, Anastasio Pantaleón de: «tan ingenioso en lo serio como donoso en lo burlesco" [VI].

Rueda, Lope de: «el prodigioso, a quien llamó el jurado de Córdoba, Juan Rufo, “inimitable varón”" [XLV].

Rufo, Juan: «el cordobés agudo» [V]; «cordobés jurado» [V]; «el pronto Rufo» [XI, XIII]; «el agudo jurado» [XI]; «el gran benemérito de la grandeza» [XI]; «el fino cordobés Rufo» [XVII]; «el agudísimo" [XX]; «Así como al jurado de Córdoba, Juan Rufo, le mudaron el nombre y le llamaron Galán suyo» [LXI].

Sá de Miranda, Francisco: «el sentencioso e ingenioso portugués».

Salas Barbadillo, Alonso Jerónimo de: «erudito y sazonado» [XXV]; «perfecto epigrama» [XXVII].

Salinas y Azpilcueta, Vicencio: «Justicia hoy de la ciudad de Huesca, meritísimo por su gran prudencia, atención, integridad y eminentísimo caudal» [XXVIII].

Salinas y Azpilcueta. Jorge: "prepósito de la santa iglesia Catedral de Huesca» [LIV]

Salinas, Conde de, Diego de Silva y Mendoza: «ornamento del saber y desempeño de la española nobleza» [XLVIII].

Salinas, Manuel: «juntó lo ingenioso de su mente y lo sabroso de su nombre» [II]; «Elegantemente lo traduce» [IV]; «el gustoso Salinas» [VI]; «con gala y propiedad» [VII]; «Anduvo muy sazonado» [VIII]; «el picante» [VIII]; «Tradújolo con la acostumbrada propiedad» $[\mathrm{XI}]$; «tan ingenioso en sus poemas cuan propio en los ajenos» [XII]; «Galantemente» [XIV]; «galante traducción» [XV]; «el galante Salinas» [XIX]; «¡Oh, qué saladamente nos lo sazona en el castellano el canónigo de Huesca!» $[\mathrm{XX}]$; «Tradújolo con bizarría» $[\mathrm{XXI}]$; «Hízole español, con propiedad y gala» $[\mathrm{XXI}]$; «el erudito» [XXVII]; «el célebre Salinas» [XXVIII]; «Siempre elegante el Salinas» [XXXI]; «No le quitó, antes le añadió sal en la traducción» [XXX]; «la valentía del Salinas pudo darle alma en el español» [XXXIII]; «Excedió a sí mismo el ingenioso y elegante» [XXXVII].

San José, Fray Jerónimo de: "conceptos graves como éste del conceptuoso y elegante en sus versos, erudito y docto en sus discursos, noticioso y grave en sus historias, nuestro aragonés y zaragozano, el religioso Padre Fray..., el religioso carmelita descalzo» [LX]. 
Santiago, Hernando de: «el mayor orador de su siglo» [XXVII]; «llamado por su agradable elocuencia Pico de Oro» [LVI].

Sanz, Pedro: "gran religioso de la Compañia de Jesús» [LI].

Sayas y Ortubia, Diego de: «esta eminencia, con la mucha sutileza ha puesto entre los de primera a nuestro aragonés y casi bilbilitano...: desempéńame con este digno epigrama» [LX].

Silvestre, Gregorio: «este epigrama del antigo Silvestre, ingenioso portugués» [XXVIII].

Soria: "Jugó de la paronomasia, creciendo sutileza el Soria, entre los antigos espańoles» [XXIV].

Tablares, Pedro de: «la ponderó el Padre Tablares, ingenioso y pío jesuita» [V].

Tapia, Juan de: «agudo Tapia, uno de los espańoles antigos» [XXV].

Tárrega, Francisco de: «aliñó ya más el verso, y tiene muy sazonadas invenciones, como la de El Principe Constante y La gallarda Irene» [XLV].

Tassis, Juan de, Conde de Villamediana: "Grandemente» [X]; "Juntó lo sentencioso con lo crítico el de Villamediana, que fue el único de nuestros tiempos en lo picante» [XVI].

Téllez Girón, Pedro, Tirso de Molina: «poeta grande» [XLIII].

Ureña, Conde de, Juan Téllez Girón: "¿Qué ingenioso el Conde de Ureña» [XXV].

Usón, Padre Juan Antonio: «nuestro ingenio aragonés de Daroca..., de la Compañía de Jesús» [LI].

Valderrama, Padre Pedro de: «el erudito» [LI]; «erudita información» [LIV].

Valdivieso, Josef de: «el grave y pío maestro..., a quien sola la Josefina bastara, sin otras muchas obras, a darle eternidad en el coro de los claros y esclarecidos ingenios, adelantó mucho esta opinión» [LX].

Vega y Carpio, Félix Lope de: "célebre Lope de Vega» [III]; "prodigioso» [IV]; «el abundante Vega» [V]; "plausible» [V]; «por lo ingenioso y por lo desengañado» $[\mathrm{V}]$; «limada canción» [VI]; "fruto de la más fértil vega» [VII]; «este valiente soneto de Lope de Vega, más conceptuoso que bizarro» [XIV]; «aunque no es muy realzado el estilo, suple con valentía del concepto, que es la parte más principal.» [XV]; «Lope de Vega, que en lo cómico sin duda excedió a todos los españoles; si no en lo limado, en lo gustoso y en lo inventivo, en lo copioso y en lo propio.» [XIX]; «formó Lope de Vega una valiente exageración en este aplaudido epigrama a Leandro; es lo mejor que hizo [«Por ver si queda en su furor deshecho»]» [XX]; «fecundo y facundo Lope» $[\mathrm{XX}]$; «con ingenioso encarecimiento» $[\mathrm{XXI}]$; «desengañado epigrama» [XXV]; «Con una artificiosa antítesi» [XXVIII]; «un bien ponderado argumento» [XXXVI]; «Fue eminente Lope de Vega, no sólo en lo fecundo, sino en lo conceptuoso; mostrólo en este valiente epigrama» [XXXVII]; "el cisne de la más fecunda vega» [XLV]; «Lope de Vega, con su fertilidad y abundancia; hubiera sido más perfecto, si no hubiera sido tan copioso; flaquea a veces el estilo y aun las trazas; tiene gran propiedad en los personajes, especialmente en los plebeyos: en las fábulas morales mereció alabanza, como aquella de El villano en su rincón, Con su pan se lo coma, La dama boba, Los 
melindres de Belisa y su excelente El Dómine Lucas.» [XLV]; "el universal Lope de Vega, que no olvida toda manera de erudición para la moral enseñanza» [LV].

Vega, Juan de: "grave y prudente» [XLIII].

Velasco, Diego de: "uno también de aquellos antigos apreciadores del saber» [XXV].

Vera y Zúńiga, Antonio de: "Así El Embajador, de don..., entre muchas muy lucidas de sus obras, fue excelente, digno de su gran ingenio en hacerle, y de los demás en lograrle.» [LVIII].

Verzosa, Juan de: "uno de los cisnes del Ebro, Juan de Verzosa, el aragonés Horacio por lo recóndito y sentencioso de sus Espistolas" [XII].

Villaizán, Jerónimo de: «Pero quien llegó a lo sumo de la perfección en estos asuntos del ingenio, fueron el conceptuoso Villaizán y el sentencioso Mendoza; parece que no se puede decir más de lo que ambos dijeron, ni llegar a más bizarría del verso, preñez de estilo, profundidad de concepto, gravedad de sentencias, invención del enredo, especialmente aquel, en la que intituló Ofender con las finezas, y éste, El marido hace mujer.» [XLV].

Villegas, Bernardino de: «feliz por lo pío y por lo ingenioso» [XXXIV].

Vitoria, Ignacio de: «el prodigioso...» [LI].

[semejanzas usadas como ripios]: «Destas no tienen ni don Luis de Góngora, ni los Leonardos, mucho menos el atento Garcilaso; escribían con total perfección» [L]. 


\section{BibliografíAS ${ }^{27}$}

Batllori, Miguel [1986], «Breve boletín graciano», Archivum Historicum Societatis Iesu, LV, 181-190.

- [1988], «Sobre Baltasar Gracián, de nuevo», Archivum Historicum Societatis Iesu, LVII, 341-351.

Cantarino, Elena [1991], «Actualidad de Baltasar Gracián. (Información y crítica bibliográfica)», Cuadernos Salmantinos de Filosofía, XVIII, 273-287.

- [1993], «Bibliografía de y sobre Baltasar Gracián», en Ayala, Jorge M., ed. [1993c], 199-221.

- [1997], «Bibliografía graciana. 1975-1995», Philosophia, 4.

- [1998] <http://flamenco.un.es/ - torrente/baltasar_gracian.htm>.

- [1998], <http://www.isid.es/users/eurema/>.

- [1999], «Bibliografía sobre Baltasar Gracián», Contrastes, 4.

Gambin, Felice [1988], «Baltasar Gracián. Prospettive del recente laboratorio bibliografico», Filosofia Politica, II, 465-471.

Hinz, M. [1987], «Zur Kritic einiger neuerer Publikationen über Baltasar Gracián», Romanitische Zeitschrift Literaturgeschichte, XI, 245-264.

Polgar, L. [1990], "Gracián Baltasar 1601-1658», en Bibliographie sur l'Histoire de la Compagnie de Jésus (19001-1980), Roma, Institutum Historicum S.I., III, 65-93.

Santos Escudero, C. [1989], «Bibliografía Hispánica de Filosofía», Pensamiento, XL, 179, 297-383.

Simón DíAz, José [1987], "Gracián, Baltasar», en Hombres y documentos de la filosofía española, Madrid, CSIC, III, 593-612.

\section{Ediciones, traducciones:}

Gracián, Baltasar, Arte de ingenio, Tratado de la agudeza. En que se explican todos los modos, y diferencias de Conceptos..., Madrid, Juan Sánchez, 1642.

- Arte de ingenio, Tratado de la agudeza, Lisboa, Oficina Craesbeeckiana, 1659.

Gracián, Baltasar, Arte de ingenio, Tratado de la agudeza, Amberes, Jerónimo y Juan Bautista Verdussen, 1669.

- Agudeza y Arte de Ingenio. En que se explican todos los modos, y diferencias de Concetos, con exemplares escogidos de todo lo más bien dicho, assí sacro, como humano. Por Lorenço Gracián. Avméntala el mesmo Autor en esta segunda impresión, con un tratado de los Estilos, su propiedad, ideas del bien hablar: con el Arte de la

27. Recojo únicamente las bibliografías posteriores a 1980. 
Erudición, y modo de aplicarla; Crisis de los Autores, y noticias de libros. Ilústrala el doctor Don Manvel de Salinas, y Lizana Canónigo de la Cathedral de Huesca, con saçonadas traducciones de los Epigramas de Marcial. Pvblícala Don Vicencio Ivan de Lastanosa..., Huesca, Ivan Nogués, 1648.

- Agudeza y Arte de Ingenio..., Huesca, Juan Nogués, 1649.

- Agudeza y Arte de Ingenio..., Amberes, Verdussen, 1702.

- Agudeza y Arte de Ingenio..., Madrid, 1720.

- Agudeza y Arte de Ingenio..., Madrid, Biblioteca de Filósofos Españoles, 1929, ed. de Eduardo Ovejero y Maury.

- Agudeza y Arte de Ingenio..., Madrid, Austral, 1942.

- Agudeza y Arte de Ingenio..., Madrid, Aguilar, 1944.

- Obras de Lorenzo Gracián [1663].

- Obras de Lorenzo Gracián, Madrid, Pablo del Val, 1664.

- Obras de Lorenzo Gracián, Barcelona, J. Suriá y Antonio Lacavallería, 1667.

- Obras de Lorenzo Gracián, Barcelona, Antonio Lacavellería, 1669.

- Obras de Lorenzo Gracián, Amberes, Verdussen, 1669.

- Obras de Lorenzo Gracián, Madrid, Imprenta Real de la Santa Cruzada, 1674.

- Obras de Lorenzo Gracián, Madrid, Imprenta Real, s.a.

- Obras de Lorenzo Gracián, Barcelona, Antonio Lacavellería, 1683.

- Obras de Lorenzo Gracián, Barcelona, Juan Jolis, 1700.

- Obras de Lorenzo Gracián, Barcelona, Jayme Suriá, s.a.

- Obras de Lorenzo Gracián, Amberes, Verdussen, 1700.

- Obras de Lorenzo Gracián, Amberes, Verdussen, 1702.

- Obras de Lorenzo Gracián, Madrid, González de Reyes, 1720.

- Obras de Lorenzo Gracián, Amberes, Verdussen, 1725.

- Obras de Lorenzo Gracián, Sevilla, A costa de D. Juan Leonardo, 1732.

- Obras de Lorenzo Gracián, Barcelona, Giralt, 1734.

- Obras de Lorenzo Gracián, Amberes, Verdussen, 1735.

- Obras de Lorenzo Gracián, Barcelona, Pedro Escuder y Pablo Nadal, 1748.

- Obras de Lorenzo Gracián, Barcelona, María Ángela Martí y Galí, 1757.

- Obras de Lorenzo Gracián, Madrid, Marín, 1773.

- Obras de Lorenzo Gracián, Barcelona, 1784.

- Obras Completas, Madrid, Aguilar, 1944, ed. de Evaristo Correa Calderón.

- Obras completas, Madrid, Aguilar, 1960, 1967, ed. de Arturo del Hoyo.

- Agudeza y Arte de ingenio, Madrid, Castalia, 1969, 1987, 2001, 2 vols., ed. de Evaristo Correa Calderón.

- Agudeza y arte de ingenio, Paramillo, 2-3 (1984), 541-829.

- Obras (Selección), Madrid, Taurus, 1983, ed. de M. Batllori.

- Art et figures de l'esprit. Agudeza y arte de ingenio, París, Editions du Seuil, 1983, trad., introd. y notas de Benito Pelegrin. 
- La Pointe ou l'Art du génie, París, L'Âge d'Homme, 1983, trad., introd. y notas de Michèle Gendreau-Massaloux y Pierre Laurens, prefacio de Marc Fumaroli.

- L'Acutezza e l'Arte dell'Ingegno, Palermo, Aesthetica, 1986, traduc. de Giulia Poggi, coord. de Blanca Perinán, introd. de Mario Perniola.

- Obras Completas, Madrid, Biblioteca Castro, Turner, 1993, ed. de Emilio Blanco, 2 vols.

- Agudeza y Arte de ingenio, México, UNAM, 1996, ed. de Gilberto Prado Galán.

- Arte de ingenio. Tratado de la Agudeza, Madrid, Cátedra, 1998, ed. de Emilio Blanco.

- Agudezay Arte de ingenio, Zaragoza, PUZ-IEA-DGA, Colec. «Larumbe. Clásicos Aragoneses», 2004, 2 vols., ed. de C. Peralta, J. M. Ayala y J. M. Andreu.

\section{Estudios críticos:}

AA.VV. [1986], Gracián y su época. Actas de la I Reunión de Filólogos Aragoneses, Zaragoza, Institución «Fernando el Católico».

Аввотт, Don Paul [1986], «Baltasar Gracián’s Agudeza: The Integration of Inventio and Elocutio», The Western Journal of Speech Communication, 50, 133-143.

Agostino, Emilia D’ [1993], «Para una estética de la sorpresa. El ingenioso arte y sus agudezas», en Jorge M. Ayala, Baltasar Gracián..., 40-45.

Aguirre, José María [1986], «Agudeza o Arte de ingenio y el Barroco», en AA.VV., Gracián y su época, 181-190.

Alonso, Santos [1981], Tensión semántica (lenguaje y estilo) de Gracián, Zaragoza, Institución «Fernando el Católico», pról. de Rafael Lapesa.

AnCeschi, Luciano [1993], "La poetica di Gracián in Europa», en Bedani, Gino, Rema Catani y Monica Slowikowska, eds., Italian Lyric Tradition: Essays in Honour of F. J. Jones, Cardiff, University of Wales, 23-36.

Andreu, José María [1993], «El ingenio como razón moral», Anthropos, 5, 173192.

- [1994], La vida moral como juego en Baltasar Gracián, Zaragoza, Centro Regional de Estudios Teológicos de Aragón (Lección inaugural del Curso Académico 1994-95).

- [1998], Gracián y el arte de vivir, Zaragoza, Institución «Fernando el Católico».

Arco y Garay, Ricardo del [1934], La Erudición Aragonesa en el siglo XVII en torno a Lastanosa, Madrid, Cuerpo Facultativo de Archiveros, Bibliotecarios y Arqueólogos.

- [1950a], La erudición española del siglo XVII y el cronista aragonés Andrés de Uztarroz, Madrid, 2 vols. 
- [1950b], «Las ideas literarias de Baltasar Gracián y los escritores aragoneses», Archivo de Filología Aragonesa, III, 27-80.

- [1953], «Baltasar Gracián y los escritores conceptistas del siglo XVII», en Historia General de las Literaturas Hispánicas, Barcelona, Vergara, III, 693-723.

ArCHer, Robert [1984], «El momento conceptuoso en un soneto de Góngora», en Ruiz Veintemilla, J. M., ed., Estudios dedicados a James Leslie Brooks, Barcelona, Puvill Libros, 15-30.

Arellano, Ignacio [1994], «El conceptismo de Góngora: más divagaciones sobre los 'déligos capotuncios' del romance 'Diez años vivió Belerma'», en Cerdan, Francis, ed., Hommage à Robert Jammes, Toulouse, Presses Universitaires du Mirail (Anejos de Criticón, 1), I, 45-52.

Aubrun, Charles, ed. [1958], Homenaje a Gracián, Zaragoza, Institución «Fernando el Católico».

AvilÉs, Luis F. [1998], Lenguaje y crisis: las alegorías de "El Criticón», Madrid, Fundamentos.

Ayala, Jorge M. [1979], "La agudeza», en Reflejo y reflexión. Baltasar Gracián. Un estilo de filosofar, Zaragoza, La Editorial, Centro Regional de Estudios Teológicos de Aragón, 25-33.

- [1986], «Naturaleza y artificio en Baltasar Gracián», en Actas del IV Seminario de Historia de la Filosofía Española, Salamanca, Universidad, 631-638.

- [1987], Gracián: vida, estilo y reflexión, Madrid, Cincel.

- [1988], «La agudeza prudencial», Criticón, 43, 7-12.

- [1989], «Baltasar Gracián y el ingenio», Cuadernos Salmantinos de Filosofía, XVI, 177-189.

- [1990], «El 'ingenio’ en Huarte de San Juan y otros escritores españoles», en Heredia Soriano, Antonio, ed., Actas del VI Seminario de Historia de la Filosofía Española e Iberoamericana, Salamanca, Universidad, 211-223.

- [1993a], «La formación intelectual de Baltasar Gracián», en Ayala, Jorge M., ed., Baltasar Gracián..., 14-38.

- ed. [1993b], Baltasar Gracián. El discurso de la vida. Una nueva visión y lectura de su obra, Barcelona, Anthropos, Documentos A, 5, 1993.

- ed. [1993c], Baltasar Gracián. Selección de estudios, investigación actual y documentación, Barcelona, Anthopos, Suplementos. Materiales de trabajo intelectual, 37.

- [1994-1995], «Tres incursiones en la filosofía de Gracián», en Moraleja, Alfonso, ed., Gracián Hoy, 145-158.

- [2001], «Un arte para el Ingenio», Trébede, 46, enero, 46-50.

[2004], "Un arte para el ingenio», en Gracián, Baltasar, Agudeza y arte de Ingenio, 
ed. de Peralte, Ceferino; Ayala, Jorge M., y Andreu, José Maa, Zaragoza, PUZIEA-DGA, Colec. Larumbe.

BACiero, L. [1967], «Una versión barroca de viejos conceptos escolásticos. Contribución al esclarecimiento de las fuentes de Gracián", Miscelánea Comillas, 47, 389-405.

Bartolomé Martínez, Bernabé [1982], «Las cátedras de Gramática de los Jesuitas en las Universidades de Aragón", Hispania Sacra, XXXIV, 389-448.

- [1995], «Baltasar Gracián», en Bartolomé Martínez, Bernabé, dir., Historia de la acción educadora de la Iglesia en España. I. Edades Antigua, Media y Moderna, Madrid, Biblioteca de Autores Cristianos, 538-549.

Bassols, Miquel [1994], "L'artifice et le réel chez Gracián (La vérité en couches)», Cahiers de l'ACF, 2, 53-59.

- [1997], "El amo de Gracián en El mundo descifrado», El sueño de la razón, 1, $12-15$.

Batllori Munné, Miguel [1958a], Gracián y el Barroco, Roma, Edizioni di Storia e Letteratura.

- [1958b], "Gracián y la retórica barroca en España», en Gracián y el Barroco, Roma, Edizioni di Storia e Letteratura, 1958, 107-114. [También en Baltasar Gracián i el Barroc, 303-310].

Batllori, Miquel [1958c], «La barroquización de la Ratio Studiorum en la mente y las obras de Gracián", en Gracián y el Barroco, Roma, Edizioni di Storia e Letteratura, 1958, 101-106. [También en Baltasar Gracián i el Barroc, 297-302].

- [1964], "La agudeza de Gracián y la retórica jesuítica», en Pierce, Frank y Jones, Cyril A., eds., Actas del Primer Congreso Internacional de Hispanistas, Oxford, The Dolphin Boocks, 57-69. [También en Cultura e Finance, 5 (1981), 225-235, y en Baltasar Gracián i el Barroc, 311-320).

- [1996], Baltasar Gracián i el Barroc, Valencia, Biblioteca d'Estudis i Investigacions, Tres i Quatre, ed. de Eulalia Durán, dir., Josep Solervicens, coord., pról. de Ceferino Peralta.

Batllori, Miquel y Ceferino Peralta [1969], Baltasar Gracián en su vida y en sus obras, Zaragoza, Institución «Fernando el Católico».

Battesti-Pelegrin, Jeanne [1985], «La lyrique du XVe siècle à travers le conceptisme de Gracián", Cahier d'Études Romanes, X, 33-56.

Beardsley, Theodore [1970], Hispano-Classical Translations printed between 1482 and 1699, Pittsburg, Duquesne University Press.

Belchior Pontes, Ma de L. [1969], "Historia Literaria e historia das ideias estéticas. A Teorização do barroco na Península Ibérica: Gracián impugnado por F. Leitão", Barroco, I, 9-14. [También en Os homens e os livros, Lisboa, Verbo, 1971, 159-169]. 
- [1971], «'A Agudeza', segundo Gracián e outros teorizadores do Barroco», en Os homens e os livros, 123-127.

Beltrán, G., "Hidalgo-Serna, Emilio, "Das ingeniose Denken bei Baltasar Gracián. Der 'concepto' und seine legische Funktion", Studia Monástica, XXIX (1987), 187. Bell, Aubrey F. G. [1921], Baltasar Gracián, Oxford, University Press.

Bethell, G. L. [1953], «Gracián, Tesauro and the Nature of Metaphysical Wit», The Northern Miscellany of Literary Criticism, I, 19-40.

Blanco, Emilio [1998], "Introducción» a Baltasar Gracián, Arte de ingenio. Tratado de la agudeza, Madrid, Cátedra.

Blanco, Mercedes [1984], «L'Epitaphe baroque dans l'œuvre poétique de Góngora et Quevedo", en Les «Formas breves»: Actes du Colloque International de BaumeLes-Aix, Aix-en-Provence, 26, 27 y 28 de noviembre de 1982, Aix-en Provence, Université de Provence, 179-194.

- [1985], «Qu'est-ce qu'un 'concepto'?», Les Langues Néo-Latines, 254, 5-20.

- [1987a], «L'arte d'ingegno e l'erotismo della novità», Baltasar Gracián. Del Barocco al Postmoderno, Aesthetica, 18, 41-53.

- [1987b], «Arte de ingenio et arte de prudencia. Le conceptisme dans la pensée politique du XVII siècle», Mélanges de la Casa de Velázquez, XXIII, 355-386.

- [1988a], «El mecanismo de la ocultación. Análisis de un ejemplo de Agudeza», Criticón, 43, 13-36.

- [1988b], «Ingenio y autoridad en la cita conceptista», en Jean-Pierre Etienvre y Leonardo Romero, eds., La recepción del texto literario (Coloquio Casa VelázquezDepartamento de Filología Española de la Universidad de Zaragoza. Jaca, abril de 1986), Zaragoza, Secretariado de Publicaciones de la Universidad de Zaragoza, 105-115.

- [1992], Les Rhétoriques de la Pointe: Baltasar Gracián et le Conceptisme en Europe, Paris, Librairie Honoré Champion.

- [1994], «Le baroque et le monstrueux. À propos de Góngora et Gracián», en Des monstres... Actes du colloque de mai 1993 à Fontenay aux Roses.

- [1995], "Les Solitudes comme système de figures. Le cas de la synecdoque», en J. Issorel, ed., Crepúsculos pisando..., 23-78.

Blecua, Alberto [2000], «Sebastián de Alvarado y Alvear, el P. Matienzo y Baltasar Gracián", en Estudios de Filología y Retórica en Homenaje a Luisa López Grijera, Bilbao, Universidad de Deusto, 77-127.

Blecua, José Manuel [1945], «El estilo de El Criticón de Gracián», en Archivo de Filología Aragonesa, serie B, I, 7-32.

- [1950], «Sobre los Argensola en la Agudeza», en Lupercio y Bartolomé Leonardo de Argensola, Rimas, Zaragoza, CSIC, V, I y II.

- [1977], «Don Luis de Góngora, conceptista», en Sobre el rigor poético en España y otros ensayos, Barcelona, Ariel, 85-90. 
- [1981a], «Francisco de la Torre, amigo de Gracián», en La vida como discurso (Temas aragoneses y otros estudios, Zaragoza, Heraldo de Aragón, 58-61.

- [1981b], «El primer escritor conceptista», en La vida como discurso, 117-119.

- [1981c], «La vida como discurso», en La vida como discurso, 294-296.

BodeI, Remo [1987], «Reverenza per: l'astuzia: Baltasar Gracián tra prudenza e agudeza», Baltasar Gracián. Dal Barocco al Postmoderno, Aesthetica, 18, 65-74.

Boloqui Larraya, Belén [1989], «Baltasar Gracián. Datos familiares inéditos (1563-1667)», en Segundo Encuentro de Estudios Bilbilitanos, Calatayud, Centro de Estudios Bilbilitanos, II, 277-305.

Bonilla y San Martín, A. [1916], "Un manuscrito inédito del siglo XVII con dos cartas autógrafas de Baltasar Gracián», Revista Crítica Hispano-Americana, 2, 121-135.

BorGHINI, Vittorio [1947], Baldassar Gracián, scrittore morale e teórico del concettismo, Milán, Áncora.

Bottiroli, G. [1986-1987], «Lo splendore delle tenebre. Etica e strategia in Baltasar Gracián", Quaderni Iberi-Americani, 61-62, 208-215.

BucETA, Erasmo [1924], «La admiración de Gracián por el infante Don Juan Manuel», Revista de Filología Española, XI, 63-66.

CABRÉ, María Dolores [1963-1965], «El poeta oscense Salinas y Gracián», Jerónimo Zurita. Cuadernos de Historia, 16-18, 275-293.

Carratello, Ugo [1974], «L'Epigrammaton liber di Marziale nella tradizione tardomedievale e umanistice», Giornale Italiano di Filologie, XXVI, 1-17.

Carreño, Antonio [1989], «Gracián y sus lecturas en el Romancero de Luis de Góngora», en Neusmeister, S., ed., Actas del IX Congreso Asociación Internacional de Hispanistas, Frankfurt am Main, Vervuert, I, 395-403.

Casas Rigall, Juan [1995], Agudeza y retórica en la poesía amorosa de cancionero, Santiago de Compostela, Servicio de Publicaciones e Intercambio Científico de la Universidad.

Castán Lanaspa, Jesús [1978], «El escritor oscense Don Francisco Antonio de Artiga y su Epitome de la Eloquencia española», Cuadernos de Aragón, 10-11, 209222.

Castro, Américo [1972], Teresa la santa, Gracián y los separatismos con otros ensayos, Madrid, Alfaguara.

Cejador y Frauca, Julio [1916], "Culteranismo y conceptismo", en "Época de Felipe III (Siglo XVII)», en Historia de la literatura castellana, Madrid, Revista de Archivos, IV, 53-69.

Cerdan, Francis [1987], «Sermones, sermonarios y predicadores citados por Gracián en la Agudeza. Apuntes bibliográficos y algunas consideraciones», en Varia Bibliographica. Homenaje a José Simón Diaz, Kassel, Reichenberger, 175-182. 
- [1993], «La emergencia del estilo culto en la oratoria sagrada del siglo XVII», Criticón, 58, 61-72.

Cerdan, Francis, y Laplana, José Enrique [1998], «Introducción» a Céspedes, Valentín, [«uan de la Encina»], Trece por docena, Toulouse, Presses Universitaires du Mirail, Anejos de Criticón, 11, 7-73.

Chala, Siegfred [1972-1973], "Conceptismo» in the «Soledades» of Góngora, Pittsburg, University.

Chambers, Leland H. [1968], "Theory and Practice in the Agudeza y Arte de Ingenio», en Flasche, Hans, ed., Litterae Hispaniae et Lusitanae: Festschrift zum Fünfzigjährigen Bestehen des Ibero-Amerikanischen Forschunsgsinstituts der Universität Hamburg, Munich, Max Hueber Verlag, 109-117.

- [1987], Baltasar Gracian's "The Mind's Wit and Art» (Ph. D. Disertación, 1962), Michigan, Ann Arbor, University Microfilms International, 2 vols.

Checa, Jorge [1998], "Gracián y las cifras del mundo», en Experiencia y representación en el Siglo de Oro, Valladolid, Junta de Castilla y León, Consejería de Educación y Cultura, 113-165.

Chevalier, Maxime [1976], «Gracián y la tradición oral», Hispanic Review, XLIV, 333-356.

- [1988a] «Conceptisme, culteranisme, agudeza», Revue XVII Siècle, 160, 281287. [Traducido en Moraleja, Alfonso, ed., Gracián Hoy, 107-115].

- [1988b], "Gracián frente a Quevedo", Nueva Revista de Filología Hispánica, XXXVI, 1069-1077.

- [1992], Quevedo y su tiempo: la agudeza verbal, Barcelona, Crítica.

- [1994], "Para una historia de la agudeza verbal», Edad de Oro, XIII, 23-29.

Collard, Andrée [1967], Nueva poesía: conceptismo, culteranismo en la crítica española, Madrid, Castalia.

Compañy, Manuel [1896], "Cartas de Baltasar Gracián y de Salinas», Revista Crítica de Historia y Literatura, I, 3, 81-88.

Correa Calderón, Evaristo [1961], Baltasar Gracián. Su vida y su obra, Madrid, Gredos [2a ed., 1970].

- [1962], "Gracián y la oratoria barroca», en Strenae. Estudios de Filología e Historia dedicados al Prof. Manuel García Blanco, Salamanca, Actas Salmanticensia, 131-138.

- [1967], «Introducción biográfica y crítica», en Gracián, Baltasar, Agudeza y Arte de Ingenio, Madrid, Castalia. [reed. 1987, 2001].

Cossío, José María de [1923], "Gracián, crítico literario», Boletín de la Biblioteca Menéndez Pelayo, V, 62-74.

Costa, Angelina [1989], "Versos y doctrina de Carrillo y Sotomayor ilustran la Agudeza y Arte de Ingenio», en Argente del Castillo, C., Granja, A. de la, Martínez 
Marín, J., y Sánchez Trigueros, A., eds., Homenaje al Prof. Antonio Gallego Morell, Granada, Universidad, I, 319-332.

Costa, Prudence Mapes [1977], "Gracián's Aesthetic of Wit in the poetry of Góngora and Donne», en DAI, XXXVII, 4336A-4337A.

Coster, Adolphe [1913], «Baltasar Gracián (1601-1658)», Revue Hispanique, XXIX, 347-754. [También en español, Zaragoza, Institución «Fernando el Católico», 1947, traduc. de R. del Arco].

Cristóbal, Vicente [1987], «Marcial en la literatura española», en Actas del Simposio sobre Marco Valerio Marcial. Poeta de Bilbilis y de Roma, Zaragoza, UNED, 147-209.

Croce, Benedetto [1899], "I Trattatisti italiani del concettismo e Baltasar Gracián», en Atti dell'Academia Pontaniana, XXX. [Traducido por J. Sánchez Rojas, en La Lectura, XII (1912), 246-247; reimp. Problemi di Estetica e contributi alla storia dell'estetica italiana, Bari, Laterza, 1940, I, 313-348].

- [1995], «Personajes de la historia italo-española. El Duque de Nocera Francisco Carafa y Baltasar Gracián», en Moraleja, Alfonso, ed., Gracián Hoy, 50-67.

Cuevas Subías, Pablo [2002], "Traduciendo a Marcial en la España de 1645 "Leandro" según Manuel de Salinas y Lizana", en Maestre Maestre, José María, ed., III Congreso Internacional de Humanismo y Pervivencia del Mundo Clásico. Homenaje a Antonio Fontán (Alcañiz, 8-13 de mayo-2000). Cádiz, Servicio de Publicaciones de la Universidad de Cádiz, t. 4, 1693-1700.

- [2001], La vida y la obra de Manuel de Salinas y Lizana (1616-1688), Zaragoza, Universidad de Zaragoza.

- [2003], «La relación del poeta Manuel de Salinas con Baltasar Gracián» en Egido, A., y otros [2003].

-[2006], ed., Manuel de Salinas, Obra poética, Zaragoza, POZ-IEA-DGA, Colec. Larumbe.

Curtius, Ernst Robert [1948], Literatura europea y Edad Media Latina, MéxicoMadrid-Buenos Aires, FCE, 1981, traduc. de M. Frenk Alatorre y A. Alatorre, 2 vols. [1 $1^{a}$ ed. en alemán].

Darbord, M. [1982], «Le paradoxe chez Gracián (1601-1658)», en Le paradoxe au temps de la Renaissance, Paris, Touzot, 41-45.

Dehennin, Elsa [1980], "Gracián, Góngora et le Baroque», en Études de Philologie et d'Histoire Littéraire offertes à Jules Horrent, Lieja, 613-622.

DíEz EChARri, Emiliano [1956], "Gongorismo y conceptismo», en La poesía vista por Menéndez Pelayo, Madrid, Editora Nacional, 156-165. [Reproduce lo dicho en Menéndez Pelayo, Historia de las Ideas Estéticas, II, 324-330, 353-358].

Dioguardi, Gianfranco [1986], Viaggo nella mente barocca: Baltasar Gracián ovvero le astuzie dell'astuzia, Palermo, Sillerio editore.

EgIDO, Aurora [1979], La poesía aragonesa del siglo XVII (Raíces culteranas), Zaragoza, Institución «Fernando el Católico». 
- [1986], «El arte de la memoria y El Criticón», en Actas de la I Reunión de Filólogos Aragoneses, 25-66.

- [1987a], «La varietà nell'Agudeza di Baltasar Gracián», Baltasar Gracián. Dal Barocco al Postmoderno, Aesthetica, 18, 25-39. [También en español, con el título «La variedad en la Agudeza de Baltasar Gracián», Sintaxis, 16-17 (1988), 49-61, y en Fronteras..., 241-258].

- [1987b], "Sobre una traducción de Agudeza y arte de ingenio» [Gracián, Baltasar, L'Accutezza e l'Arte dell'Ingegno. Traduzione di Giulia Poggi. Consulenza scientifica e coordinamento da Blanca Perinán, Palermo, Aesthetica Edizioni, 1986], Criticón, 39, 127-136.

- [1987c], «La Hidra bocal. Sobre la palabra poética en el Barroco», Edad de Oro, VI, 79-113 [Repr. en Fronteras de la poesía en el Barroco, Barcelona, Crítica, 1990].

- [1988], «Baltasar Gracián y la Agudeza», en Alvar, Manuel, dir., Enciclopedia Temática de Aragón. 7. Literatura, Zaragoza, Moncayo, 194-205.

- [1993], «La letra en El Criticón», Bulletin Hispanique, 95, 557-586.

- [1994], "La vida cultural oscense en tiempos de Lastanosa», en Luesma, Teresa, ed., Signos. Arte y Cultura en Huesca. De Forment a Lastanosa. Siglos XVI-XVII, Huesca, Gobierno de Aragón-Diputación Provincial de Huesca.

- [1996], La rosa del silencio: estudios sobre Gracián, Madrid, Alianza.

- [1997]. Introducción a B. Gracián, El Discreto, Madrid, Alianza.

- [1998], «La Nobleza virtuosa de la Condesa de Aranda, dońa Luisa de Padilla, amiga de Gracián», Archivo de Filología Aragonesa, LIV-LV, 9-41.

- [2000], Las caras de la prudencia y Baltasar Gracián, Madrid, Castalia [especialmente «La "circunstancia especial" en la Agudeza» y «El concepto de Historia (Fray Jerónimo de San José)»].

- [2001a], "Un nuevo Arte de ingenio: la Agudeza de Gracián y las artes liberales», en Humanidades y dignidad del hombre en Gracián, Salamanca, Universidad.

- y Marín, Ma Carmen [2001b], eds., Baltasar Gracián: estado de la cuestión y nuevas perspectivas, Zaragoza, DGA-IFC.

- Gil Encabo; Laplana, J. Enrique [2003], eds., Baltasar Gracián IV Centenario (1601-2001). Actas I Congreso Internacional «Baltasar Gracián»: pensamiento y erudición» (Huesca, 23-26 de mayo de 2001), Zaragoza, IFC-IEA-Gobierno de Aragón.

Emancini, G. [1988], «Las referencias religiosas en la Agudeza y arte de ingenio», Revista de Filología Española, LXVIII, 1-11.

FLOR, Fernando R. de la [1995], «La oratoria sagrada del Siglo de Oro y el dominio corporal», en Díez Borque, J. M., ed., Culturas en la Edad de Oro, Madrid, Ed. Complutense. 
Frago García, Juan Antonio [1993], «Actitud de Gracián ante el hecho lingüístico», en Ayala, Jorge M., ed., Baltasar Gracián..., 68-74.

Fumaroli, M. [1983], La pointe ou l'art du génie, Paris, L’Âge de l'Homme [Préface].

Galera Sánchez, Matilde [1984], "Alonso de Bonilla, origen del conceptismo andaluz», en Peláez del Rosal, Manuel, y Rivas Carmona, Jesús, eds., El Barroco en Andalucía, Córdoba, Ediciones El Almendro, 44-46.

Gallagher, Patrick [1984], «La manzana hipócrita: erotismo cromático, humor e ironía en las agudezas orgánicas del Polifemo de Góngora», en Ruiz Veintemilla, J. M., ed., Estudios dedicados a James Leslie Brooks, Barcelona, Puvill Libros, S.A., 45-60.

Gambin, Felice [1991], «Le parole e il silenzio: per un approdo alle due biblioteche italiane di Baltasar Gracián», Rassegna Iberistica, 39, 17-24.

García Berrio, Antonio [1968], España e Italia ante el conceptismo, Murcia, Universidad.

- [1977], Formación de la teoría literaria moderna. La tópica horaciana, Barcelona, Cupsa Editorial-Planeta.

- [1980], Formación de la teoría literaria moderna. Teoría poética del Siglo de Oro, Murcia, Departamento de Lengua Española.

García Gibert, Javier y Hernández Sacristán, Carlos [1988], «El razonamiento etimológico como procedimiento discursivo en Baltasar Gracián», Archivo de Filología Aragonesa, XLI, 153-172.

García Soriano, Justo [1927], «Reivindicaciones. Los dos 'modos' literarios: conceptismo y culteranismo", La Gaceta Literaria, I, 11.

Garzelli, Beatrice [2000], "Dall'Arte de Ingenio al Criticón: Percosi di Letteratura italiana nell'ottica barocca del Padre Gracián», en Martinengo, Alessandro, ed., Gracián desde Italia. Cinque studi, Lucca, Mauro Baroni editore, 107-136.

Gates, Eunice Joiner [1968], «Poetic Compositions by Andrés de Uztarroz in Honor of a Novice», en Homage to John M. Hill. In Memoriam, Indiana University, $19-44$.

Gendreau-Massaloux, Michèle [1980], «La variación intertextual, clave ideológica», en Alonso Hernández, J. L., ed., Teorías semiológicas aplicadas a textos españoles. Actas del I Symposium Internacional del Departamento de Español de la Universidad de Groningen (21, 22 y 23 de mayo de 1979), Zamora, Universidad de Groningen, 69-81.

Gendreau-Massaloux, Michèle, y Laurens, P. [1981], «Racines et fruits de la Agudeza y arte de ingenio de Baltasar Gracián: la naissance d'une nouvelle rhétorique», en Permanence, émergences et résurgences culturelles dans le monde ibérique et ibéro-americain, Aix-en-Provence, Université de Provence, 149-163.

Gil Fernández, Luis [1981], «Los jesuitas y la selección de autores», en Panorama 
social del humanismo español (1500-1800), Madrid, Alhambra, 536-545 [2a ed. ampliada en 1997].

Gili GaYa, Samuel [1958], «Agudeza, modismos y lugares comunes», en Aubrun, Ch., ed., Homenaje a Gracián, 89-97.

Giulian, Anthony A. [1930], Martial and the epigrama in Spain in the sixteenth and seventeenth centuries, Filadelfia, University of Philadelphia.

Goded y Mur, Anonio [1962], "Quinientas sesenta referencias a Aragón y a lo aragonés en la obra de Gracián», Zaragoza, XVI, 131-165.

Goldin, J. [1978], "Jeux de l'esprit et de la parole: d'une rhétorique à l'art de la pointe», Filologie, 69, 129-140.

Gómez de Liaño, Ignacio [1994-1995], «Gracián o la crítica de la razón simbólica», en Moreleja, Alfonso, ed., Gracián hoy..., 116-144.

González Casanova, P. [1953], «Verdad y agudeza en Gracián», Cuadernos Hispanoamericanos, 70, 143-160.

Grady, Hugh H. [1980], «Rhetoric, Wit and Art in Gracián's Agudeza», The Modern Language Quaterly, XLI, 21-37.

Graziani, Françoise [1986], "Le concetto dans le sonnet», en Bellenger, Ysonne, ed., Le sonnet à la Renaissance. Des origines au XVII siècle, París, Aux amateurs de livres.

Green, Otis H. [1958], «Sobre el significado de 'crisi(s)' antes de El Criticón. Una nota para la historia del conceptismo», en Aubrun, Ch., ed., Homenaje a Gracián, 99-102.

Guardiola Alcover, Conrado [1980], Baltasar Gracián. Recuento de una vida, Zaragoza, Librería General.

Hafter, Monroe Z. [1966], Gracián and perfection, Cambridge, Harvard University Press.

Hammond, J. H. [1950], Francisco Santos' indebtedness to Gracián, Austin, University of Texas.

Hartmann, Susanne [1986], Baltasar Gracián: Sehnsucht nacht dem verlorenen Paradies: 'concepto' und Weltanschauung, Hamburgo, Romanisches Seminar der Univ. Hamburgo.

Hatzfeld, Helmut [1972], «Poéticas barrocas. Tres deformaciones nacionales de Aristóteles: Tesauro, Gracián, Boileau», en Estudios de Literaturas Románicas, Barcelona, Planeta, 259-278.

Heger, Klaus [1960], Baltasar Gracián. Estilo lingüistico y doctrina de valores. Estudio literario sobre la actitud literaria del conceptismo, Zaragoza, Institución «Fernando el Católico», 1982 (2a ed.; en alemán, 1952).

Hernández, María Teresa [1985-1986], «La teoría literaria del Conceptismo en Baltasar Gracián», Estudios de Lingüística, 3, 7-46. 
Herrero García, Miguel [1942], Sermonario clásico, Madrid-Buenos Aires, Escelicer.

Herrero Salgado, Félix [1993], "La oratoria sagrada en el siglo XVII: tradición e innovaciones», en García Martín, M., Arellano, I., Balsco, J., Vitse, M., eds., Estado actual de los estudios sobre el Siglo de Oro. Actas del II Congreso Internacional de Hispanistas del Siglo de Oro, Salamanca, Ediciones de la Universidad.

- [1996], La oratoria sagrada en los siglos XVI y XVII, Madrid, F.U.E.

Hidalgo-Serna, Emilio [1980], "The Philosophy of Ingenium: Conceit and Ingenious Method in Baltasar Gracián", Philosophy and Rhetoric, 13, 245-263.

- [1985], Das ingeniöse Denken bei Baltasar Gracián. Der 'concepto' und seine legische Funktion, Munich, Wilhelm Fink Verlag. [traducido al italiano con el título Baltasar Gracián. La logica dell’ingegno, Bolonia. Nuova Alfa, 1989, y publicado en español como El pensamiento ingenioso en Baltasar Gracián: el "concepto» y su función lógica, Barcelona, Anthropos, 1993].

- [1987], «Il problema filosofico dell'Agudeza y arte de ingenio», Baltasar Gracián. Dal Barocco al Postmoderno, Aesthetica, 18, 9-23.

- [1988a], «Función cognoscitiva, estética y moral del 'juicio ingenioso'», Diálogo Filosófico, IV, 167-177. [Reprod. en ES, 11 (1998), 167-177.

- [1988b], «El 'buen gusto’ en Gracián. Acepción y destino europeo de una metáfora en cifra", en Körner, K.-H., Vitse, M., Harrassowitz, O., eds., Las influencias mutuas entre España y Europa a partir del siglo XVI, Weisbaden, 6978.

- [1989], «Origen y causas de la 'agudeza': necesaria revisión del 'conceptismo' español», en Neumeister, Sebastian, ed., Actas del IX Congreso Asociación Internacional de Hispanistas, Frankfurt am Main, Vervuert Verlag, II, 477-486.

- [1991], «La 'agudeza de acción’ en El Héroe», en Neumeister, Sebastian, y Dietrich Briesemeister, eds., El mundo de Gracián, 161-170.

Hinz, Manfred [1999], "Mentire con la verità. Baltasar Gracián e Juan Manuel», Annali di Storia Moderna e Contemporanea, V, 43-64.

JANKÉLÉVITCH, Vladimir [1958], "Apparence et manière», en Aubrun, Ch., ed., Homenaje a Gracián, 119-129. [Traducido en Moraleja, A., ed., Gracián Hoy, 76-87).

Jansen, Helmunt [1958], Die Grundbegriffe des Baltasar Gracián, Ginebra, Droz.

- [1983], "Genio e Ingenio», en Ayala, Jorge M., ed., Baltasar Gracián..., 154155.

Jiménez Moreno, Luis [1964], «Sobre el conocimiento barroco de Baltasar Gracián en Arte y Agudeza de Ingenio", The Romanic Review, LV, 85-90.

- [1991], Práctica del saber en filósofos españoles: Gracián, Unamuno, Ortega y Gasset, E. d'Ors, Tierno Galván, Barcelona, Anthropos, pról. Nelson R. Orringer. 67-70. 
Juste SÁnchez, María Rosario [1987], «Marcial y la poesía aragonesa de la segunda mitad del siglo XVII", en Marco Valerio Marcial. Poeta de Bilbilis y de Roma, Zaragoza, UNED, 125-129.

Krabbenhoft, Kenneth [1994], El precio de la cortesía: retórica e innovación en Quevedo y Gracián: un estudio de la "Vida de Marco Bruto" y del "Oráculo manual $y$ arte de prudencia», Salamanca, Ediciones Universidad.

Krauss, Werner [1962], La doctrina de la vida según Baltasar Gracián, Madrid, Rialp.

L.E.S.O. (UA 1050 del CNRS) [1986], «Doscientas cincuenta notas para una mejor comprensión literal de la primera parte del Criticón», en Criticón, 33, 51-104.

L.E.S.O. (UA 1050 del CNRS) [1988], «Trescientas notas para una mejor comprensión literal del Criticón (Segunda y tercera parte)», en Criticón, 43, 189245.

Labrador Herráiz, Carmen [1992], «Estudio histórico-pedagógico», en Eusebio Gil, ed., El sistema educativo de la Compañia de Jesús. La "Ratio Studiorum», Madrid, Universidad Pontificia de Comillas.

LAPlana Gil, José Enrique [1993], «La oratoria sagrada del seiscientos y el escritor aragonés Ambrosio Bondía», en Enguita, José María, ed., Actas del II Curso sobre Lengua y Literatura en Aragón (Siglos de Oro), Zaragoza, Institución «Fernando el Católico», 79-118.

- [1998], «Noticias y documentos relativos a la biblioteca del Colegio de la Compañía en Huesca», Voz y Letra, IX/I, 123-140.

- [2000], "La Agudeza y arte de ingenio de Baltasar Gracián, y la predicación», en Sobre agudeza y conceptos de Baltasar Gracián. Simposio filosófico-literario (16 y 17 de abril de 1999), Zaragoza, Diputación Provincial de Zaragoza-UNED, 83-97.

Larsen, Kevin [1981], "The Presence of Luis de Camoens in Gracián's Agudeza y arte de ingenio», Mester, X, 4-13.

Laurens, P. [1979], "Ars ingenii: la théorie de la pointe au dix-septième siècle (B. Gracián, E. Tesauro)», La Licorne, 3, 185-213.

- [1980], «Martial, ou l'épigramme grecque et latine de l'époque alexandrine à la fin de la Renaissance (Champ, structures et développement) ", L'Information Littéraire, XXXII, 5, 201-206.

- [1986], «Du modèle idéal au modèle opératoire: La théorie épigrammatique aux XVI ${ }^{e}$ et XVII ${ }^{e}$ siècles», en Lafond, J., ed., Le modèle à la Renaissance, Paris, J. Urin, 183-208.

Laurenti, Joseph L. [1965], «La admiración de Baltasar Gracián por Italia», Archivo Hispalense, XLIII, 265-276. [También en Les Langues Néo-Latines, 205 (1973), 41-51].

Lázaro Carreter, Fernando [1977], «Sobre la dificultad conceptista», en Estilo barroco y personalidad creadora, Madrid, Cátedra, 13-44. 
- [1986], "El género literario de El Criticón», en AA.VV., Gracián y su época, 67-87.

LEDDA, Giuseppina [1982], «Forma e modi di teatralità nell'oratoria sacra del'600», Studi Ispanici, 87-107.

- [1985], «Introducción» a Pérez de Ledesma, Gonzalo [seudónimo del P. José de Ormaza], Censura de la Elocuencia (Zaragoza, 1648), Madrid, El Crótalón, ed. de Ledda, G., y Stagno, V., 9-36.

- [1989a], "Antiguos y nuevos predicadores: una polémica sull'oratoria sacra dell'600», en Periñán, B., Guazzelli, F., eds., Symbolae Pisanae. Studi in onore di Guido Mancini, Pisa, Giardini Editori.

- [1989b], «Predicar a los ojos», Edad de Oro, IX, 129-142.

López SANTos, Luis [1946], «La oratoria sagrada en el seiscientos. Un libro inédito del P. Valentín de Céspedes», Revista de Filología Española, XXX, 353-368.

Lund, C. [1977], «Francisco Leitao Ferreira's Nova arte de conceitos: A Portuguese apology for the conceit in the tradition of Gracián and Tesauro", Luso-Brasilian Review, XIV, 60-75.

Maldonado de Guevara, F. [1957], «Del 'Ingenium’ de Cervantes al de Gracián», Anales Cervantinos, VI, 97-111.

Mancini, Guido [1988], "Las referencias religiosas en la Agudeza y arte de ingenio», Revista de Filología Española, LXVIII, 1-11.

Manso, Francisco [1966], "Gracián y el senequismo aragonés», en Octava Semana Española de Filosofía. Estudios sobre Séneca, Madrid, CSIC-Instituto Luis Vives de Filosofía, 373-380.

Marras, Gianna Carla [1996], "Elocuencia española en arte de Jiménez Patón y Agudeza y arte de ingenio de Baltasar Gracián", en Arellano, Ignacio et al., eds., Studia aurea. Actas del III Congreso de la AISO (Toulouse, 1993), III, Prosa, Pamplona, GRISO-LEMSO-M.AA.EE., 323-326.

MARTí, José [1972], La preceptiva retórica en el Siglo de Oro, Madrid, Gredos.

Martinengo, Alessandro [1992], "Cibi picanti, foglie amare (e letteratura) in Gracián», en Profeti, Maria Grazia, ed., Codici del Gusto, Milán, Franco Angeli, 302-312.

Martínez-López, Enrique [1969], "Culteranismo, conceptismo peninsular en Brasil», en Revista Iberoamericana, XXXV, 303-327.

Marzot, G. [1944], L'ingegno e il genio nel Seicento, Florencia, La Nuova Italia.

May, Terence E. [1948], "An interpretation of Gracián's Agudeza y arte de ingenio», Hispanic Review, XVI, 275-300. [Reimp. en Wit of the Golden-Age, 1986, 2952].

- [1950], "Gracian's Idea of the 'Concepto'", Modern Language Review, XLV, 319-335. [Reimp. ", Hispanic Review, XVIII, 15-41, y en Wit of the Golden Age. Articles on Spanish Literature, Kassel, Edition Reichenberger, 1986, 53-79]. 
- [1986b], «Notes on Gracián's Agudeza», en Wit of the Golden-Age, 270-283.

Mehnert, K. H. [1979], «Der Begriff 'ingenio’ bei Juan Huarte und Baltasar Gracián», Romanische Forschungen, 91, 270-280.

Menéndez Pelayo, Marcelino [1884], "Conceptismo, Gongorismo y Culteranismo. Sus precedentes, sus causas y sus efectos en la Literatura Española», en Historia de las ideas estéticas en España, Madrid, Imp. de A. Pérez Dubrull. [Reimp. Madrid, CSIC, 1940, 1974, I, 832-837].

Menéndez Pidal, Ramón [1942], "Obscuridad, dificultad entre culteranos y conceptistas», Romanische Forschungen, LVI, 211-218. [Reimp. en Castilla: la tradición, el idioma, Buenos Aires, Espasa-Calpe, 1945, 219-232; Madrid, Espasa-Calpe, 1966, 218-230].

- [1956], «Sobre la dificultad conceptista», en Estudios dedicados a Menéndez Pidal, Madrid, Espasa-Calpe-CSIC, VI, 372-374.

- [1983], «El hermetismo barroco: oscuridad y dificultad como ideales estéticos», en Rico, Francisco, dir., Wardropper, Bruce A., ed., Historia y Crítica de la Literatura Española. 3. Siglos de Oro: Barroco, Barcelona, Crítica, 99-102.

Metschies, M. [1967], "'Concepto' und Zitat», Romanische Forschungen, LXXIX, 152-157.

Milburn, D. Judson [1966], The Age of Wit (1650-1750), Nueva York, McMillan Co.

Moll, Jaime [1996-1997], «Las ediciones madrileñas de obras sueltas de Gracián», Archivo de Filología Aragonesa, LII-LIII, 117-124.

Monge, Félix [1966], «Culteranismo y conceptismo a la luz de Gracián», en Homenaje. Estudios de Filología e historia literaria lusohispanas e iberoamericanas publicados para celebrar el tercer lustro del Instituto de Estudios Hispánicos, Portugueses e Iberoamericanos de la Universidad Estatal de Utrecht, La Haya, Van Goor Zonen, 355-381.

Monge, Félix, A Collard y A. A. Parker [1983], "Conceptismo y culteranismo», en Rico, Francisco, dir., Wardropper, Bruce A., ed., Historia y Crítica de la Literatura Española. 3. Siglos de Oro: Barroco, Barcelona, Crítica, 103-112.

Moraleja Juárez, Alfonso, ed. [1994-1995], Gracián Hoy, Madrid, Cuaderno Gris, Monográfico.

- [1999], Baltasar Gracián: forma política y contenido ético, Madrid, Universidad Autónoma.

Morel-Fatio, A. [1910], "Liste chronologique des lettres de Balthasar Gracián dont l'existence a été signalée ou dont le texte a été publié», Bulletin Hispanique, XII, 204-206.

Muñoz García de Iturróspide, María Teresa [1995], «Adaptaciones de Marcial en autores ingleses y españoles en los siglos XVI-XVII», Castilla, 17, 297-313.

Navarro González, Alberto [1948], "La dos redacciones de la Agudeza y arte de 
ingenio», Cuadernos de Literatura Comparada, IV, 201-213.

- [1986], "Garcilaso y Gracián», Academia Literaria Renacentista, IV, 247-269.

Neumeister, Sebastian, y Dietrich Briesemeister, eds. [1991], El mundo de Gracián. Actas del Coloquio Internacional, Berlín, 1988, Berlín, Colloquium Verlag.

Nider, Valentina [1991], «'Reparo' y 'reparar': apuntes sobre el léxico de la Agudeza $y$ arte de ingenio", Criticón, 53, 97-108.

Orotbig, Christine [1992], «Gracián lector de Don Juan Manuel a través de Argote de Molina», Criticón, 53, 117-133.

Orozco, Emilio [1980], «Sobre la teatralización del templo y la función religiosa en el barroco: el predicador y el comediante», Cuadernos para la investigación de la literatura hispánica, II-III, 171-188.

Ovejero y Mauri, Eduardo [1929], «Resumen de su vida y juicio de su obra», en Gracián, Baltasar, Agudeza y arte de ingenio, Madrid, Imp. La Fara, «Biblioteca de Filósofos Españoles».

Parga y Pondal, Salvador [1930], "Marcial en la preceptiva retórica de Baltasar Gracián", Revista de Archivos, Bibliotecas y Museos, LI, 219-247.

Parker, Alexander A. [1956], "La agudeza en algunos sonetos de Quevedo. Contribución al estudio del conceptismo", en Estudios dedicados a Menéndez Pidal, Madrid, Espasa-Calpe, CSIC, III, 345-360. [Reimp. en Sobejano, Gonzalo, ed., Francisco de Quevedo, Madrid, Taurus, 1978, 44-57].

- [1982], "Concept' and 'conceit': An aspect of Comparative Literary History», The Modern Languaje Quaterly, LXXVII, XXI-XXXV.

Patella, Giuseppe [1996], «Il bello 'acuto’ di Baltasar Gracián», en Lono, M., ed., Le ragioni del bello, Padua, Gregoriana, 91-104.

- [1993], Gracián o della perfezione, Roma, Edizioni Studium.

Pedraza, Felipe B., y Milagros Rodríguez [1980], "Conceptismo y culteranismo», en Manuel de Literatura española. III. Barroco: Introducción, prosa y poesía, EstellaPamplona, Cénlit, 66-72.

Pelegrin, Benito [1980], «La retórica ampliada al placer», Diwan, 8/9, 35-80.

- [1985a], Éthique et estéthique du Baroque. Espace jésuitique de Baltasar Gracián, Arles, H. Nyssen.

- [1985b], Le Fil du "Criticón» de Baltasar Gracián: Objectif Port-Royal. Allégorie et composition "conceptiste», Aix-en-Provence, Université de Provence.

- [1986], «De una poética de la escritura a una escritura poética (De Agudeza y arte de ingenio a Criticón), en Teoría del discurso poético, Toulouse, Unviversité de Toulouse-Le Mirail, 195-206.

- [1987], «Fra Antichi e Moderni. Gracián dall'Agudeza al Criticón», Baltasar Gracián. Dal Barocco al Postmoderno, Aesthetica, 18, 55-64. 
- [1988] «Gracián, admirateur pirate de don Juan Manuel», Bulletin Hispanique, LXXX, 197-214.

- [1993], «Física y metafísica del estilo de Baltasar Gracián», en Ayala, Jorge M., ed., Baltasar Gracián..., 46-67.

Peralta Abad, Ceferino [1984a], «El eclecticismo estético de Baltasar Gracián en la Agudeza», Studia Histórica et Philologica in honorem M. Batllori, Anexos de Pliegos de Cordel, III, 763-773.

- [1984b], «Ideas lingüísticas subyacentes en los escritos de Baltasar Gracián (1601-1658)», Archivum Historicum Societatis Jesu, III, 331-349.

- [1984c], «Gracián, entre barroco y neoclásico en la Agudeza», Paramillo, 2-3, 543-554.

- [1986], «La ocultación de Cervantes en Baltasar Gracián», en AA.VV., Gracián y su época, 137-156.

Pérez Lasheras, Antonio [1995], Más a lo moderno (Sátira, burla y poesía en la época de Góngora), Zaragoza, Trópica.

- [2001a], "Agudeza y arte de ingenio; la belleza del fragmento", Trébede, 46, enero, 29-31.

- [2001b], "Arte y agudeza: "poética de la escritura", retórica del gusto", FGL, en prensa.

- [2001c], "Arte y Agudeza: "poética de la escritura”, retórica del gusto», Boletín de la Fundación Federico García Lorca, 29-30, 91-105.

- [2001d], «Arte de Ingenio y Agudeza y Arte de ingenio», en Egido, A., y Marín, $\mathrm{M}^{\mathrm{a}}$ Carmen, eds., 71-88].

Periñán, Blanca [1977], «Lenguaje agudo entre Gracián y Freud», Studi Ispanici, 69-94.

- [1993], «Gracián y Freud», en Ayala, Jorge M., ed., Baltasar Gracián..., 166171.

Perniola, Mario [1986], Presentación a Gracián, Baltasar, L'Acutezza e l'Arte dell'Ingegno, Palermo, Aesthetica, traduc. de G. Poggi.

- [1987], "Saperi intermedi», Baltasar Gracián. Dal Barocco al Posmoderno, Aesthetica, 18, 95-102.

- [1991], Del sentire, Turín, Einaudi, 76-87.

Perugini, Francesca [1993], «Baltasar Gracián lettore dei moralisti antichi», en

Canone, Eugenio, ed., Bibliothecae Selectae da Cusano a Leopardi, Florencia, Leo

S. Olschki, 525-530.

Poggi, Giulia [1986], «Góngora, Gracián e l'albero del misterio», Studi Ispanici, 83-122.

- [1993], «Le 'agudezas' di Tadeo (sul ruolo linguistico del 'gracioso' ne Las Firmezas de Isabela», Quaderni di Lingua e Letterature, XVIII, 577-595. 
Pozuelo Yvancos, José María [1980], «Sobre la teoría y praxis literaria en el conceptismo: un tópico de Quevedo a la luz de la teoría literaria de Gracián», Cuadernos Hispanoamericanos, 361-362, 40-54.

Profeti, Maria Grazia [1993], «L'Acutezza e l'Arte dell'Ingegno di Gracián», en Importare letteratura: Italia e Spagna, Roma, Edizioni dell'Orso, 211-216.

Ramos Foster, Virginia [1969], «Baltasar Gracián y los conceptos de la poesía antes de la Agudeza y arte de ingenio", Hispanófila, XII, 33-43.

- [1970], "A Note on Gracián'Agudeza y arte de ingenio and Baroque Esthetics", Romance Notes, XI, 611-616.

- [1975], Baltasar Gracián, Boston, Twayne.

Reckert, Tina [1990], Der metaphorische "concepto» als Grundlage der ingeniosen Sprache bei Baltasar Gracián, Dissertation, Brauschweig.

- [1993], "Metáfora y concepto metafórico en Agudeza y arte de ingenio», en Ayala, Jorge M., ed., Baltasar Gracián..., 81-86.

Ricard, R. «Wit and Agudeza» [1948], Revue du Moyen Âge Latin, 4, 283-285.

Rodríguez Pequeño, M. [1997], "Verdad y ficción en literatura: la agudeza compuesta fingida de B. Gracián», Revista de Literatura, LIX, 399-421.

Roig Miranda, Marie [1988], "Le concepto dans les sonnets de Quevedo», i n Chevalier, J. C., y M.-F. Delport, eds., Mélanges offerts á Maurice Molho, París Éditions Hispaniques, I, 537-555.

Romera-Navarro, Miguel [1940], «Dos aprobaciones de Gracián», Hispanic Review, VIII, 257-263.

- [1947], «La antología de Alfay y Baltasar Gracián», Hispanic Review, XV, 325-345.

- [1950a], Estudios sobre Gracián, Austin, University of Texas.

- [1950b], «Cuestiones gracianas. 1. Amistad y rompimiento entre Gracián y Salinas», en Estudios dedicados a Menéndez Pidal, Madrid, Espasa-Calpe-CSIC, I, 359-362.

Romo Feito, Fernando [1993], "La paradoja en Agudeza y arte de ingenio», en Ayala, Jorge M., ed., Baltasar Gracián..., 97.

Roses Lozano, Joaquín [1990], "Sobre el ingenio y la inspiración en la edad de Góngora», Criticón, 49, 31-49.

- [1993], Una poética de la oscuridad: la recepción crítica de las «Soledades» en el siglo XVII, Londres, Tamesis, prefacio de R. Jammes.

Rothberg, Irving Paul [1954], The Greek Anthology in Spanish Poetry: 1500-1700, Michigan, The Pennsylvania State University.

- [1956], "Covarrubias, Gracián and the Greeck Anthology», Studies in Philology, LIII, 540-552.

- [1981], «Neoclassical wit and Gracián’s theory of 'agudeza': John Owen’s 
Epigrammatum in Spanish Translation», Romanische Forschungen, XCIII, 82-102.

Rozas, Juan Manuel [1986], «El compromiso moral en la Agudeza (y en las Poesías varias de Alfay)», en AA.VV., Gracián y su época, 191-200.

Ruiz Ruiz, José M. [1981], "Agudeza y arte de ingenio de Gracián y An essay on criticism de Pope», E.S., II, 35-82.

Runcini, Romolo [1987], «La inquietudini del mondo e l'ordine delle acutezze», Aesthetica, XVIII, 75-93.

SÁInz de Robles, Federico Carlos [1957], "Conceptismo», en Los Movimientos Literarios (Historia, interpretación y crítica), Madrid, Aguilar, 38-43.

SÁnchez Escribano, Federico [1961], «Gracián ante la comedia española del siglo XVII», Revista de Literatura, XIX, 113-115.

Saraiva, A. J. [1980], «O 'conceito’ segundo Baltasar Gracián e Matteo Peregrini ou duas concepçoes seiscentistas do discurso", en O Discurso Engenhoso, Sao Paulo, Editora Perspectiva, 125-146.

Sarmiento, Edward [1932], "Gracián’s Agudeza y Arte de ingenio», Modern Language Review, XXVII, 280-292 y 420-429.

- [1935], «On Two Criticisms of Gracián’s Agudeza», Hspanic Review, III, 23-35.

- [1958], «Sobre la idea de una escuela de escritores conceptistas en Espańa», en Aubrun, Ch., ed., Homenaje a Gracián, 145-153.

Schulz-Buschinaus, Ulrich [1986], «Hidalgo-Serna, Emilio, «Das ingeniöse Denken bei Baltasar Gracián. Der 'concepto' und seine logische Funktion», Romanische Forschungen, XCVIII, 229-232.

- [1991], "Gattungsbewusstsein und Gattungsnivellierung bei Gracián», en Neumeister, Sebastian, y Dietrich Briesemeister, eds., El mundo de Gracián, 75-94.

Sebastián, Santiago [1995], Emblemática e Historia del arte, Madrid, Cátedra.

Selig, Karl Ludwig [1958], «Some Remarks on Gracián’s Literary Taste and Judgements», en Aubrun. Ch., ed. Homenaje a Gracián, 155-161.

- [1960], The Library of Vicencio Juan de Lastanosa, patron of Gracian, Ginebra, Librairie Droz.

- [1978], "Gracián and Alciato's Emblemata», Comparative Literature, VIII (1956), 1-11. [Ampliado en Emblem und Emblematikrezeption, Darmstadt, Wissenschaftliche Buchgesellschaft, 122-139].

- [1991], «La Agudeza y el arte de citar», en Neumeister, Sebastián, y Dietrich Briesemeister, eds., El mundo de Gracián..., 67-74.

Senabre, Ricardo [1979], Gracián y «El Criticón», Salamanca, Universidad.

Sierra de Cózar, Ángel [1999], "Epigramas latinos 'anónimos' en Agudeza y Arte de ingenio, de Gracián: notas e identificaciones»", en Aldama, A. Ma $M^{\mathrm{a}}$ F. del 
Barrio, M. Conde, A. Espigares, Ma J. López de Ayala, eds., La Filología Latina hoy. Actualización y perspectivas, Madrid, Sociedad de Estudios Latinos, II, 13231330.

SiLES, Jaime [1982], «Erotismo y Barroco: singularidad de un modo culto de ficción», en Diversificaciones, Valencia, Fernando Torres-Editor, 47-52.

Smith, Hilary Dansey [1978], Preaching in Spanish Golen Age, Oxford, University Press.

- [1986], «Baltasar Gracián’s Preachers: Sermón-Sources in the Agudeza», Bulletin of Hispanic Studies, LXIII, 327-338.

Solano Camón, Enrique, [1989] «Notas acerca del significado histórico del P. Gracián en torno a 1640», Criticón, 45, 71-80.

Spadaccini, Nicholas y Jenaro Talens [1997], eds., Rhetoric and Politics: Baltasar Gracian and the New World Order, Minneapolis, University of Minnesota Press.

SchröDer, Gerhart [1985], Logos und List. Zur Entwicklung der Äesthetik in der frühen Neuzeit, Athenäum, Königstein/Ts, 93-149 y 248-256.

Strolle, Jon M. [1972], "Gracián and gusto», Kentucky Romance Quarterly, XIX, 485-500.

Thirouin, Laurent [1990], «La pensée du hasard chez Gracián et la Rochefoucauld», Les Langues Néo-Latines, 273, 17-40.

VAíllo, Carlos [1992], "Gracián y la prosa de ideas», en Francisco Rico, dir., Historia y Critica de la Literatura Española. III. Primer Suplemento, Barcelona, Crítica, 1992, 488-525.

- [1989], «Los franceses, antípodas de los españoles en Gracián», en Imágenes de Francia en las Letras Hispánicas, Barcelona, PPU, 417-425.

Valbuena Prat, Ángel [1970], «El diverso conceptismo de Quevedo y Gracián», Revista de la Universidad de Madrid, XIX, 249-270.

Wardropper, Nancy Palmer [1976-1977], "Some unidentified poetic fragments in Gracián’s Agudeza», Revista Hispánica Moderna, XXXIX, 49-51.

- [1980-1981], "The editions of 1648 and 1649 of Gracián's Agudeza y arte de ingenio", Journal of Hispanic Philology, V, 137-157.

- [1985], Baltasar Gracian's Two Interpretations of the Variety of «Agudeza»: 1642 and 1648, Baltimore, The Johns Hopkins University [Michigan, Ann Arbor, University Microfilms International, 1989].

- [1989], «El Discurso III de la Agudeza y arte de ingenio de Baltasar Gracián: 'Variedad de la agudeza' ", en Sebastián Neumeister, ed., Actas del IX Congreso de la Asociación Internacional de Hispanistas, Frankfort am Main, Vervuert, I, 569574.

- [1993], "Gracián sobre la erudición y la agudeza», en Ayala, Jorge M., ed., Baltasar Gracián..., 75-80.

Werle, Peter [1991], "Arte de ingenio. Überlegungen zur Gattungszugehörigkeit 
des Graciánchen Traktats», en Neumeister, Sebastian, y Dietrich Briesemeister, eds., El mundo de Gracián, 95-108.

Woods, M. J. [1968], "Gracián, Peregrini, and the Theory of Topics», Modern Languages Review, LXIII, 854-863.

- [1968], «Sexteenth-Century Topical Theory: Some Spanish and Italian Views», Modern Languages Review, LXIII, 66-73.

- [1995], Gracián meets Góngora. The Theory and Practice of Wit, Warsminster, Aris \& Phillips, Ltd.

Ynduráin, Domingo [1994], Humanismo y Renacimiento en España, Madrid, Cátedra.

Ynduráin, Francisco [1958], "Gracían, un estilo», en Aubrun, Ch., ed., Homenaje a Gracián, 163-188.

Zamora, Bonifacio [1951], «¿Qué dice el Padre Gracián de la Reina Isabel?», Boletín de la Institución Fernán González, XXX, 725-739.

Zárate Ruiz, Arturo [1996], Gracián, Wit, and the Baroque Age, Nueva York, Peter Land. 